Claremont Colleges

Scholarship@Claremont

WM Keck Science Faculty Papers

W.M. Keck Science Department

$1-1-2010$

\title{
An Extraordinary Example of Photokarren in a Sandstone Cave, Cueva Charles Brewer, Chimantá Plateau, Venezuela: Biogeomorphology on a Small Scale
}

Joyce Lundberg

Carleton University

Donald A. McFarlane

Claremont McKenna College; Pitzer College; Scripps College

Charles Brewer-Carias

Sociedad Venezolanda de Ciencias Naturales

\section{Recommended Citation}

J. Lundberg, D.A. McFarlane, C. Brewer-Carias, An extraordinary example of photokarren in a sandstone cave, Cueva Charles Brewer, Chimantá Plateau, Venezuela: Biogeomorphology on a small scale, Geomorphology, Volume 121, Issues 3-4, 15 September 2010, Pages 342-357, ISSN 0169-555X, 10.1016/j.geomorph.2010.05.005.

This Article is brought to you for free and open access by the W.M. Keck Science Department at Scholarship @ Claremont. It has been accepted for inclusion in WM Keck Science Faculty Papers by an authorized administrator of Scholarship @ Claremont. For more information, please contact scholarship@cuc.claremont.edu. 


\title{
An extraordinary example of photokarren in a sandstone cave, Cueva Charles Brewer, Chimantá Plateau, Venezuela: Biogeomorphology on a small scale
}

\author{
J. Lundberg a,*, D.A. McFarlane ${ }^{\text {b }}$, C. Brewer-Carias ${ }^{c}$ \\ a Department of Geography and Environmental Studies, Carleton University, Ottawa, Ontario, Canada K1S 5B6 \\ ${ }^{b}$ W.M. Keck Science Center, The Claremont Colleges, Claremont, CA 91711, USA \\ c Sociedad Venezolana de Ciencias Naturales, Edif Torre America PH-B, Ave. Venezuela, Bello Monte Caracas, Venezuela
}

\section{A R T I C L E I N F O}

\section{Article history:}

Received 21 July 2009

Received in revised form 30 March 2010

Accepted 7 May 2010

Available online $\mathrm{xxxx}$

\section{Keywords:}

Photokarren

Sandstone

Cave

Tepui

Diatom

Biofilm

\begin{abstract}
A B S T R A C T
A distinctive suite of small-scale erosional forms that are oriented towards the light occur close to the entrance of Cueva Charles Brewer, a large cave in a sandstone tepui, in SE Venezuela. These are the third example of photokarren ever studied in the world, the other two being from Borneo and Ireland. They are the only photokarren ever described from sandstone, and the only example from a non-carbonate environment. The host rock is a poorly-lithified unit of the Precambrian quartz arenite of the Roraima Supergroup. The forms are all oriented towards the light at $30^{\circ}$ regardless of rock surface orientation. The primary (negative) erosional form is the tube. Coalescence of tubes results in the positive remnant forms of rods, pinnacles, and cones. The final stage is a bumpy, wavy surface of degraded cones. The size of the features varies with erosion rate, and details of the form vary with development stage. The main population averages $4.4 \mathrm{~cm}$ in depth, with $55 \%$ of the surface eroded. This is divided into $10 \%$ tubes, $70 \%$ rods, $10 \%$ cones, $5 \%$ linear valley and $5 \%$ wavy lowland. The micro-ecosystem includes many bacteria, diatoms, red algae, green algae, liverworts, and oribatid mites, but, surprisingly, no cyanobacteria. The presence of a surface biofilm inside the forms but not on the remnant rock surface and, in the non-degraded forms, the direct relationship of biomass with depth suggests that biological activity is the dominant control on development. In addition, direct bacterial corrosion was noted. These same features occur to varying extents in the photokarren of Borneo and Ireland, and the model for development that we present provides a unifying theory for all photokarren. (This study also includes the first published petrographic analysis of uppermost unit of the Mataui Formation).
\end{abstract}

(c) 2010 Elsevier B.V. All rights reserved.

\section{Introduction}

The Cueva Charles Brewer system, Venezuela, is currently the largest sandstone cave in the world (Šmída et al., 2005) at $\geq 23 \mathrm{~km}$ long (unpublished data from 2009 expedition). It is developed at the top of Chimantá Plateau, one of the isolated tepuis in south-east Venezuela (Fig. 1). The tepuis are mesas or table mountains in Precambrian quartzites and sandstones. The cave is unique in many respects (for examples see Aubrecht et al., 2008a,b). In this paper we document one of its smaller features - a set of very delicate and beautifully carved photokarren - a feature that is relatively unusual even in limestone caves and has never before been reported in sandstone.

Inside caves or rock shelters in sandstone, the rock surfaces are usually simply rounded, smoothed by abrasion, fractured by collapse, or spalled from exfoliative processes. The features described here are

\footnotetext{
* Corresponding author. Tel.: + 1613520 2600x2571; fax: +1 6135204301 . E-mail addresses: joyce_lundberg@carleton.ca (J. Lundberg),

dmcfarlane@jsd.claremont.edu (D.A. McFarlane), charlesbrewercarias@gmail.com (C. Brewer-Carias).
}

quite different - they are small, straight-sided pits, tubes or cones that are distinctly angled towards the light and floored by a green biomat. They occur only in a narrow band close to the cave entrance within the zone of very low light. We have included them under the term photokarren because they have all the appearance of the phototropic erosional features described from limestone cave entrances in other localities in the world (and this comparison is based on first-hand observation of these other examples). However, these features are rare: to our knowledge, photokarren have been studied only in Sarawak in Borneo (Bull and Laverty, 1982) and Ireland (Simms, 1990; Porter, 2003) - in both cases developed in hard limestone. Fig. 2 demonstrates the similarity of the features from Sarawak in limestone and from Venezuela in sandstone.

\subsection{Definitions and description}

"Biokarst" refers to all organically-influenced karst features (Viles, 2004). "Phytokarren" or "photokarren" are small-scale landforms produced by the action of "plants" on "limestone" surfaces (Viles, 2004). Most phytokarst features consist of pits with remnant upstanding areas, usually randomly or gravitationally oriented. The 


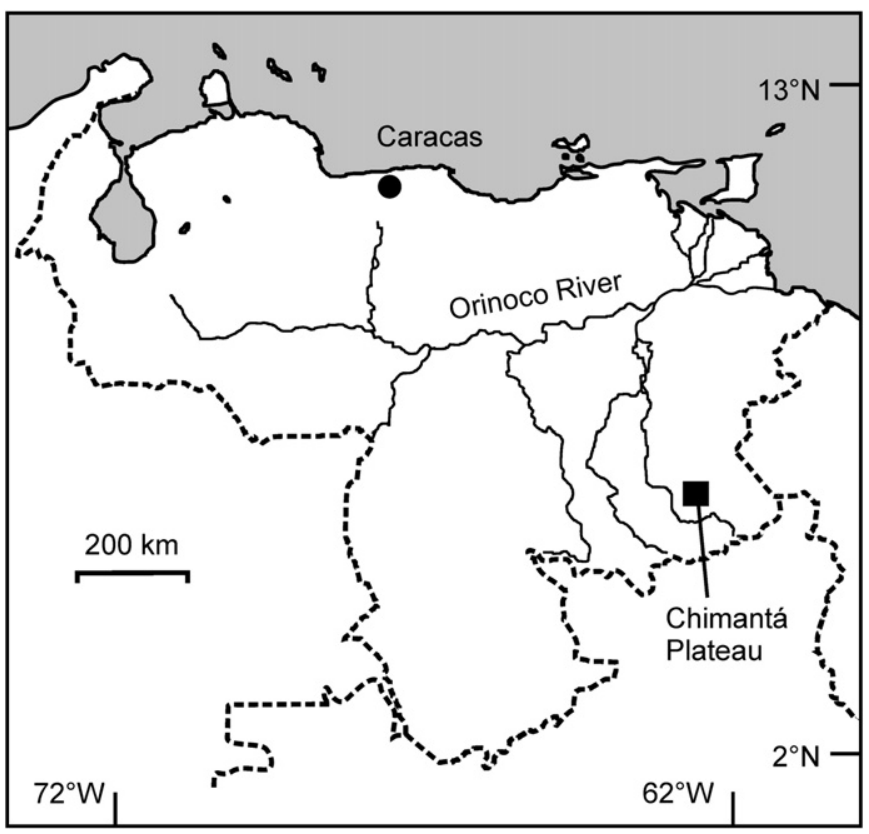

Fig. 1. Location of Chimantá Plateau in S.E. Venezuela.

term "photo-" is reserved for those features that are oriented towards the light, and "karren" for erosional rather than depositional features: for example, the blue-green speleothems that are oriented towards the light are not photokarren, although they might be included under photokarst and certainly are a form of biokarst. So, light-oriented erosional features can be classified in a hierarchy: first they are biokarst (because they are organically-influenced); then they are phytokarst (because they are made by photosynthesizing organisms); then they are photokarren (because they are light-oriented and erosional). These terms presuppose that organic activity is the formative agent: although direct proof of this is rarely possible (unless the biological activity is boring of rock surfaces), the intimate association of biological activity and geomorphology implies a causative connection. In this study, we document the morphology, distribution, and associated biological activity of photokarren features developed in sandstone rather than limestone, thus implicitly extending Viles' (2004) rather limited definition to include nonlimestone lithologies.

The first publication that mentions 'photokarren' specifically appears to be Brook and Waltham (1978, p.41) in a very brief reference to the Borneo examples. Laverty (1981) observes that they were called 'photokarren' when first discovered, but then Bull and
Laverty (1982) adopted the more general term 'phytokarst' adding the adjective 'directed'. Simms (1990) reverts to the original term, as do we.

Small-scale light-oriented pinnacles and pits have been studied in only two places in the world. The most famous example is from the tropical cave entrances of Clearwater Cave and Green Cave, Gunung Mulu National Park in Borneo (Waltham and Brook, 1980; Laverty, 1981; Bull and Laverty, 1982). Laverty (1983) notes in passing that photokarren are also found in the Penrissen (Kuching) district of Sarawak, Borneo. The other main location is temperate caves in the west of Ireland just above marine high tide level (Simms, 1990). Finally, brief mention is made of photokarren in entrances of old phreatic caves breached by marine erosion in the north of Ireland (Porter, 2003).

Bull and Laverty (1982), who use the term 'directed phytokarst', describe light-oriented pinnacles and cones up to $120 \mathrm{~mm}$ long, assumed to be produced by boring or dissolution by the filaments of red and blue-green algae (cyanobacteria) that colour the rock surface light green. Directed beams of light result in elongate rods or cones. Laverty (1981) describes at least two distinct morphological forms, either a sheaf of rods of several millimeters diameter and up to $10 \mathrm{~cm}$ long, or an arrangement of jagged spearheads up to $50 \mathrm{~cm}$ in length and $10 \mathrm{~cm}$ basal diameter. These may be bladed or conical. Their shape varies with inclination of the rock surface in relation to light: if light incidence is parallel to the surface, then ribs form; if it is perpendicular, then cones form. Bull and Laverty (1982) introduce another form - 'striations' - which develop where the angle of light incidence is sub-parallel to the rock surface. Their field data indicate a range from $1 \mathrm{~cm}$ average depth for the least developed up to $8 \mathrm{~cm}$ average for the deepest. They present a classification of phytokarst, in which the 'directed phytokarst' are divided into 'hollows (lacework)' (by which they mean the "black phytokarst from Hell" of Folk et al., 1973) and 'residuals' this latter being then divided into 'striations', 'rods' and 'cones'. These are the simple forms - they become more "bulky, wavy" on the larger scale (perhaps the 50-cm long forms of Laverty, 1981).

The photokarren from Ireland are in a very different environment limestone cave entrances close to the sea. These are obviously not tropical, and apparently only occur in the unroofed sections of fossil caves that are now in the supra-tidal zone, where colonization by photosynthesizing algae modifies the originally scalloped surfaces. Simms (1990) describes, from the Burren district, pinnacles, blades and cones oriented to the angle of light incidence. They are deeper in the more direct light and their form changes in relation to elevation above sea level (but the seawater has no dissolutional effect). Photokarren form only above the intertidal zone. The lowermost pinnacles are blunt, becoming sharper and almost vertical further up. The best development is at 3.5 to $4 \mathrm{~m}$ above low water mark (LWM)
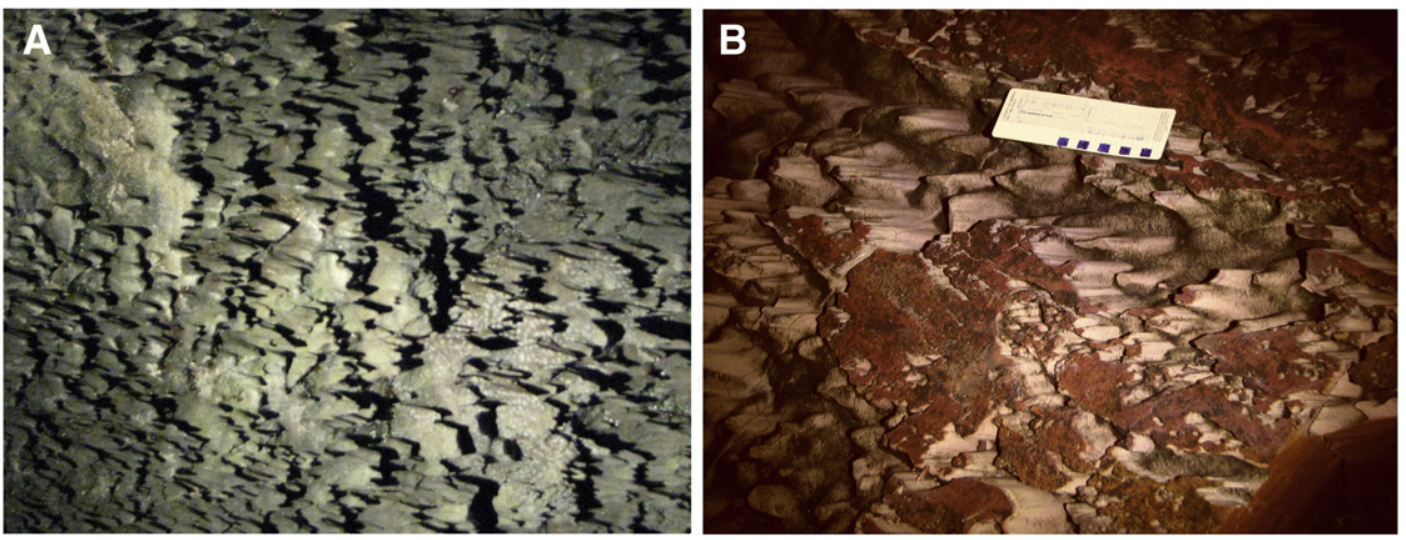

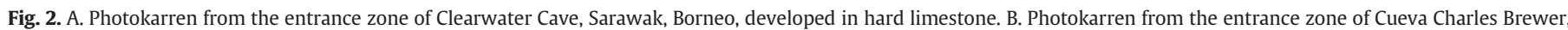
Venezuela, developed in soft sandstone. 
where the pinnacles are $\sim 6 \mathrm{~cm}$ long, with a base $\sim 2-3 \mathrm{~cm}$ wide. Beyond this they get smaller and disappear at $\sim 5 \mathrm{~m}$ above LWM. The sharpest, largest, and most blade-like pinnacles are on dimly-lit faces. With decreasing light the blades merge into flakes and terraces. With increasing light they become more conical. The photokarren in the old phreatic cave entrances of Antrim, Ireland, are simply described as 'blind tubes' a centimeter or more in diameter and several centimeters deep (Porter, 2003).

The features developed in the dimly-lit entrance zone of Cueva Charles Brewer that we describe below have many of the features mentioned in these other studies. Their morphology fits the published descriptions of photokarren in that they are a suite of tubes, rods, pinnacles and cones that are oriented towards the light. However, they are on sandstone, and it is a quartz arenite - not a sandstone with a calcite matrix or cement that might easily dissolve. In spite of the very different chemistry, their form is so similar that a similar mode of formation is implied and the obvious association with biological material (which we document below) suggests that biogeochemical processes are important.

\subsection{Geological and geographical setting}

The properties of the host rock are usually an important control on geomorphological processes. The host rock here is variously and loosely referred to as 'quartzite' or 'sandstone' (e.g., Šmída et al., 2005; Aubrecht et al., 2008a,b). These rocks are not the very hard metamorphosed sandstones that we would normally associate with the term 'quartzite' - the more precise description is a quartz arenite. The tepuis are the westernmost outliers of the Guiana Shield, formed largely of Precambrian silicate arenites of the Roraima Supergroup, ranging in age from 2.3 to $1.4 \mathrm{Ga}$ (Piccini and Mecchia, 2009). The tepuis are developed mainly in the uppermost unit - called the Mataui Formation - which has not been directly dated, but can be presumed to be close to the minimum age of $1.66 \pm 0.06 \mathrm{Ga}$ (Gibbs and Barron, 1993), and certainly younger than $1.87 \pm 0.03 \mathrm{Ga}$ (Santos et al., 2003). Gibbs and Barron (1993) note that strictly they should be called "quasi-Roraima", being from a separate sedimentary basin; however, their characteristics are very similar. Gibbs and Barron (1993) describe the main mass of the Roraima Supergroup as a fairly mature quartz sandstone with a recrystallized matrix of sericitic quartzite, but with immature arkosic sandstones locally. They are relatively horizontal sedimentary rocks that have had only very low-grade burial metamorphism, and some local contact metamorphism from diabase intrusions (Piccini and Mecchia, 2009). Ripples and crossbedding are a common feature of the sandstone. The very low-grade metamorphism has caused some interstitial quartz overgrowth with variable white mica giving a saccharoid structure.

The rocks exposed in the cave have not previously been studied petrographically, but Aubrecht et al. (2008a,b) observe that they are extraordinarily inhomogeneously lithified, varying from hard orthoquartzites to very much softer beds of barely-lithified arkose sandstone. On the macro-scale the rocks display their sedimentary texture, with many ripple marks and cross beds. In spite of their great age and potential for structural deformation, these beds display little evidence of alteration or metamorphism. The bed hosting the majority of the photokarren is so poorly lithified that it can be broken by trampling. The rock itself is white to pale pink in colour. Deposition from percolation waters has case-hardened many of the bedding planes, ripple surfaces, and fracture surfaces with a red-coloured, iron-rich, relatively smooth, harder patina. This patina is exposed on many of the bedding planes throughout the cave and likely developed long before the cave was formed. The patina is an important feature since it is through this that the photokarren must initially be cut in order to get established in the softer white rock.

Cueva Charles Brewer is developed within the uppermost 150$200 \mathrm{~m}$ of the tepui. The cave entrance is at the base of a $70 \mathrm{~m}$ sheer cliff that is north-west facing (Fig. 3) giving only a narrow ingress for light. The features were observed both in the bedrock floor of the cave close to the stream level and in large (stable) boulders at higher levels. The majority of photokarren is developed in the zone of low light $\sim 100 \mathrm{~m}$ inside the cave and at floor level (Fig. 3). The light level can be estimated, using trigonometry and distance from the entrance, as approximately $3 \%$ of the illumination immediately inside the cave entrance. A definitive feature is that they all conform quite closely to the same angle - namely $30^{\circ}$ from the horizontal regardless of the orientation of the rock surface - as can be seen in Fig. 4. The asymmetry of the form increases as the angle of repose of the rock surface approaches the angle of incidence of the light.

The formation of the cave is well documented in Aubrecht et al. (2008a,b) and Šmída et al. (2005). Here we present a short summary, largely to show the environment of the photokarren and to show that the photokarren are not subject to the normal speleogenetic processes. The caves of the tepuis are generally sub-horizontal river passages that follow the bedding planes, interrupted by collapse piles. Galleries are typically $40 \mathrm{~m}$ wide but can be much larger. The most likely speleogenetic processes are winnowing and erosion of beds of poorly-lithified arenites that are sandwiched between well-cemented beds. The caves form when drainage water from the very wet tepui summits gets access to the poorly-lithified beds through fractures. Fluvial action is obvious: the occasional sand deposit on the floor indicates the winnowing action and the fluvial erosion/deposition processes. Some parts of the cave-bearing beds are better lithified and support pillars. Progressive collapse is evident throughout the cave, leading to rather large chambers, and in places large collapse zones have broken through to the tepui surface. Few of the features in the cave suggest dissolution as an important process although condensation waters were found to be chemically aggressive (Lánczos et al., 2007).

For this study we mapped the distribution of the photokarren, documented their form and dimensions, and took a sample for laboratory study. Since rock properties are often important for development of small-scale features, we studied one sample of rock that hosted photokarren and one that did not. Since biological action has been implicated in other photokarren (Viles, 2009), we studied the distribution and type of biomass at several scales. We had two basic aims: to record the features as well as possible; and to assess the role of chemical, physical and biological activities.

\section{Methods}

The distribution of photokarren was mapped on the cave survey (from Šmída et al., 2005). The size and morphology of the features were documented in the field. They were classified into three groups according to level of development. For each group, photographs were taken in order to facilitate mapping. The orientation of the features was mapped in relation to incident light. The distribution of surficial visible green matter was mapped in detail for several examples, in relation to light, and to rock properties. A sequence of development was produced on the basis of the morphologies observed.

A sample (which had already been broken by an unwary caver) was taken for microscopic and chemical analysis. This was kept damp, in darkness, and at approximately the same temperature as in the cave. The intact surface was photographed under reflected light using Zeiss Discovery V20 and Axioplan 2 microscopes (Carleton University Biology Department). Slides were made of scrapings from the surface and photographed using transmitted light. Scrapings of the surface were shaken in distilled water to try to remove the firmly attached green matter from the surface of the sand grains, and the resulting suspension examined under light microscope. The mites that were found were fixed by lactic acid digestion for a few hours to clear internal organs, and then mounted in polyvinyl alcohol (PVA) and cured overnight on gentle heat. 


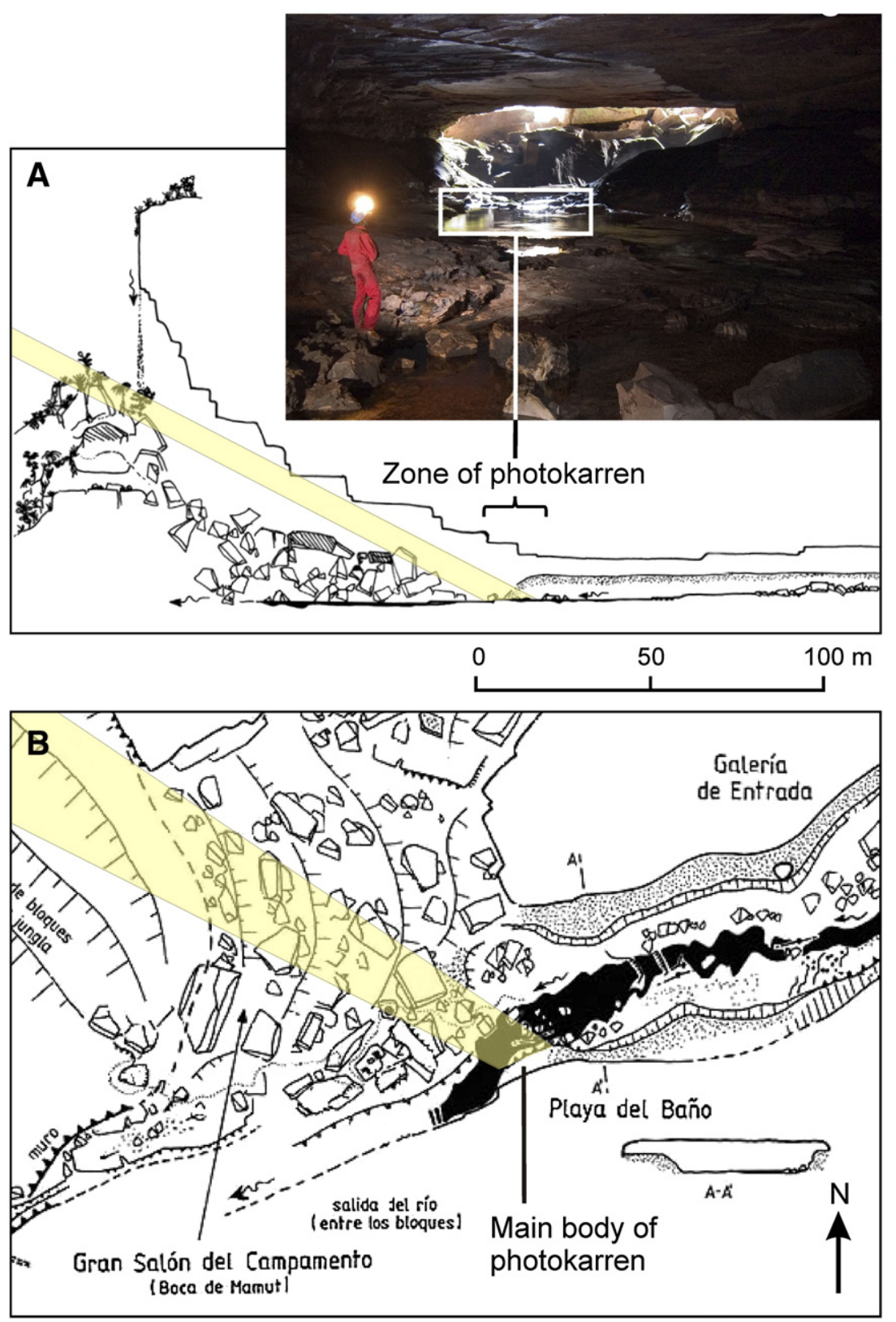

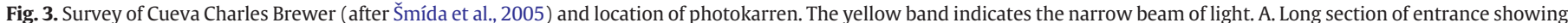

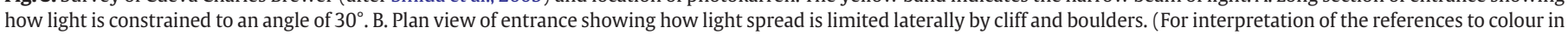
this figure legend, the reader is referred to the web version of this article.)

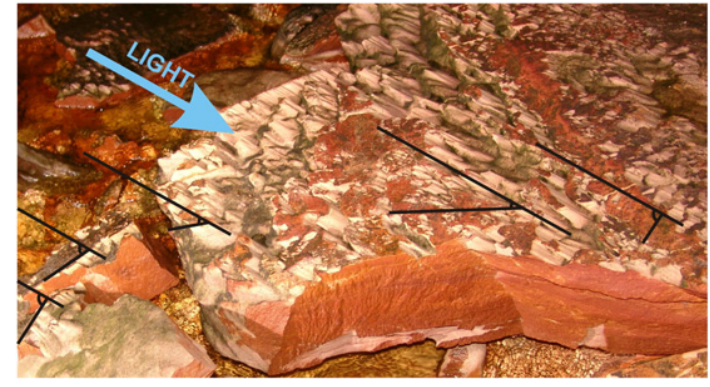

Fig. 4. The main section of photokarren: the angle of the axis of the form is always the same as the angle of the incidental light (shown by the blue arrow) at $30^{\circ}$ to the horizontal, regardless of the angle of the surface of the rock. The black lines show the varying angles made by the photokarren and the original rock surface. The bright red colour is only a surface patina on the white rock. The green is organic. (For interpretation of the references to colour in this figure legend, the reader is referred to the web version of this article.)
Three samples were prepared for Scanning Electron Microscopy (SEM) and Energy Dispersive Spectral (EDS) analysis using a Tescan Vega II XMU machine (Carleton University). The samples with living matter were fixed in $3 \%$ gluteraldehyde ( $\mathrm{pH}$ buffered to 7.0 with $0.1 \mathrm{M}$ $\mathrm{NaPO}_{4}$ ) for $24 \mathrm{~h}$, followed by $1 \%$ osmium tetroxide for $2 \mathrm{~h}$. The water was replaced by ethanol (stepwise from 30\% up to 100\%) for $24 \mathrm{~h}$. Then they were dried to critical point (in an Emitech K850 Critical Point Dryer) using $\mathrm{CO}_{2}$, and mounted on stubs for SEM.

Three rock samples were analyzed for major $\left(\mathrm{SiO}_{2}, \mathrm{TiO}_{2}, \mathrm{Al}_{2} \mathrm{O}_{3}, \mathrm{Fe}_{2} \mathrm{O}_{3}\right.$, $\mathrm{MnO}, \mathrm{MgO}, \mathrm{CaO}, \mathrm{Na}_{2} \mathrm{O}, \mathrm{K}_{2} \mathrm{O}, \mathrm{P}_{2} \mathrm{O}_{5}$ ) and trace ( $\mathrm{Ba}, \mathrm{Ce}, \mathrm{Co}, \mathrm{Cr}, \mathrm{Ga}$, $\mathrm{La}, \mathrm{Nb}, \mathrm{Nd}$, $\mathrm{Ni}, \mathrm{Pb}, \mathrm{Rb}, \mathrm{Sr}, \mathrm{Th}, \mathrm{U}, \mathrm{V}, \mathrm{Y}, \mathrm{Zn}$ and $\mathrm{Zr}$ ) elements and Loss On Ignition (LOI) by $\mathrm{X}$-Ray Diffraction (XRD) and X-Ray Fluorescence (XRF) at the University of Ottawa. The XRD analysis was performed on a Philips 3020 X'Pert system. The samples were prepared as a packed powder. The XRF analysis was performed on a Philips PW2400 sequential wavelength-dispersive XRay Fluorescence spectrometer. The samples were prepared as fused disks of $4 \mathrm{~g}$ of flux (mixture of lithium borates) and $1 \mathrm{~g}$ of sample. 
Two $30 \mu \mathrm{m}$ thin sections were prepared for petrological study at Carleton University Earth Sciences Department. The softer rock was impregnated in resin before cutting. These were imaged using plane polarized light ( $\mathrm{ppl}$ ) and crossed nicols (xn).

\section{Results}

\subsection{Geomorphology results}

\subsubsection{Distribution of photokarren in cave}

The main population of photokarren is limited to a narrow band close to the cave entrance in the penumbral zone of very low light intensity. This is only about $14 \mathrm{~m}$ wide and restricted to the southern side of the passage. The angle of the cave roof and floor admit only a very limited arc of light, such that the angle of light in the penumbral zone remains close to $30^{\circ}$ from the horizontal. Most of the photokarren are found on in-situ bedrock close to the stream, but they also develop above the stream, and on boulders at various angles of repose. A few poorly-developed examples can be found scattered amongst the high level boulders, where the light levels are low. No photokarren were found further towards the cave entrance in the higher light zones. The importance of light is proven by the few exceptions to the rule. Bull and Laverty (1982) noted that the only cases where photokarren were not oriented to the light were on boulders that had been moved. We found one case where a photokarren-boulder had been flipped over by fluvial action (but not yet broken up - photokarren closest to the stream are often destroyed by fluvial action), and thus removed from the light. It had lost all its green covering and the karren were no longer oriented towards the light.

\subsubsection{Relationship of form and distance from light}

There is a clear variation in size, density and, to some extent, form of the photokarren with distance from light. The forms vary gradationally but were divided for study into three zones: Zone A, the innermost zone, is the least lit and has the smallest forms; Zone B, the main body of photokarren, is moderately well lit, and has the deepest forms; Zone $\mathrm{C}$, the outermost zone, is the best lit and the forms are mostly remnant. Fig. 5 shows for each zone a photograph and a map of the intact red patina from which measures of percentage cover were made. The photographs were taken with different cameras - in reality the green colours are brighter for all zones and the red patina is about the same for all as in photo $B$. The maps were produced by tracing the outlines in Corel Draw and the breakdown of areas using the program Image (National Institutes of Health, 2009). Cross sections are shown in Fig. 6.
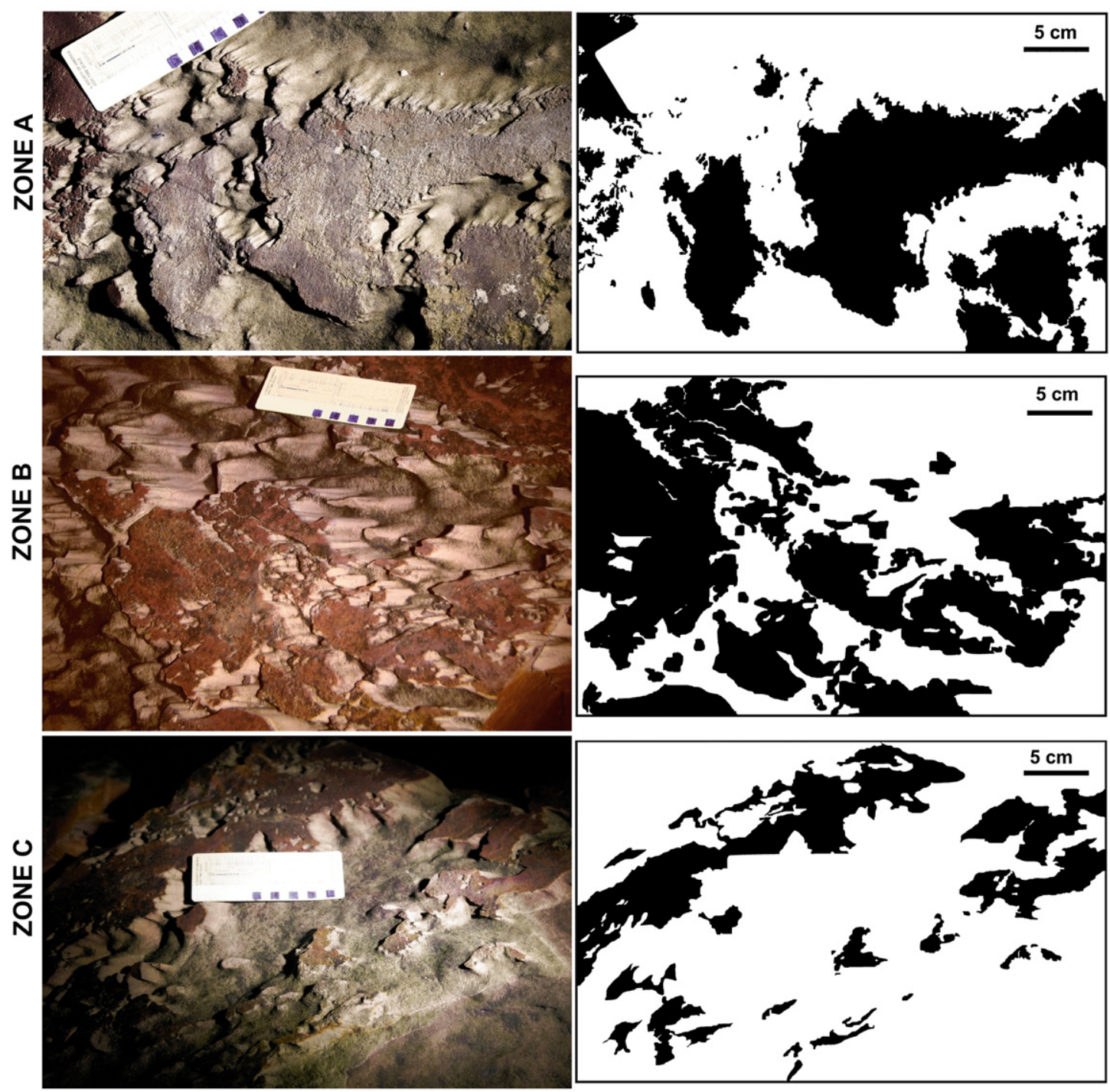

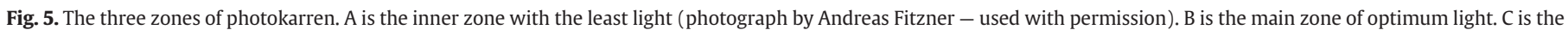
outer zone where forms are mostly remnant. The maps of the isolated tops are all of the same area $-1066 \mathrm{~cm}^{2}$. 


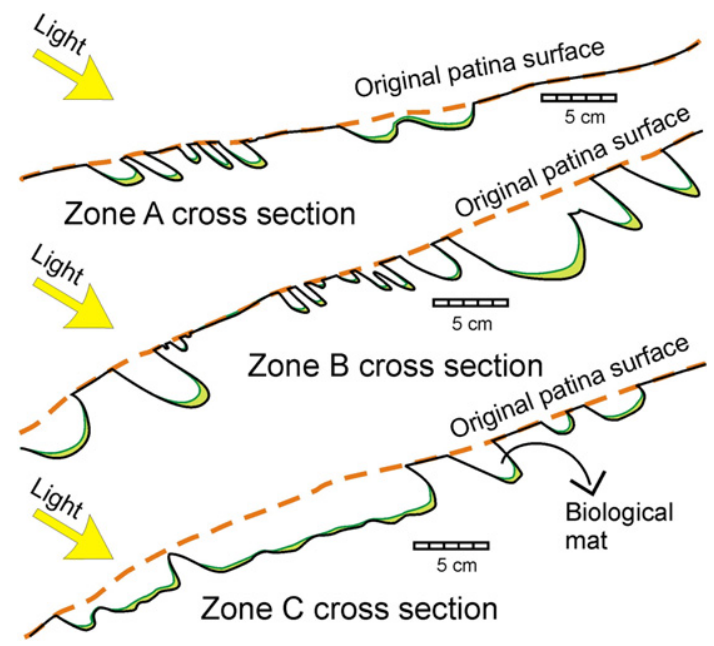

Fig. 6. Cross sections for each of the photokarren zones. The dashed red line shows the original patina surface, of which little is left in Zone C. The green colouring is an indication of the location of the biological material - this is a little exaggerated for clarity. In reality the thickest mat, in the floors of the photokarren, is emergent from the surface by only about $2 \mathrm{~mm}$. (For interpretation of the references to colour in this figure legend, the reader is referred to the web version of this article.)

Data on each zone are presented in Table 1. Depth was measured down the central axis of each (i.e., at $30^{\circ}$ ). Cover value was estimated first in the field for the whole zone. The second set of \% cover numbers in Table 1 is for the single samples of $1066 \mathrm{~cm}^{2}$ area. The calculation of $\%$ cover was used because it was not possible to estimate density (so we cannot directly compare density values with Bull and Laverty, 1982). Classification of types of karren was done by eye. Fractal dimensions were calculated as an attempt to quantify the nature of the crenulations - these are useful to compare the three zones. These were done by simple box counting using the program Fractalyse (Vuidel, 2006) with the size of the box changing exponentially (squared each time). However, the outcome is very dependent on the method of calculation, which has never been standardized in these kinds of studies. We recommend that future studies employ quadratical grid counting, where grid distance $\varepsilon$ varies to the power of 2 , to facilitate inter-study comparisons.

Table 1

Geomorphological data on the zones.

\begin{tabular}{llll}
\hline & Zone A & Zone B & Zone C \\
\hline Average depth \pm St. Dev. $(\mathrm{cm})$ & $1.6 \pm 0.3$ & $4.4 \pm 1.9$ & $2.6 \pm 0.8$ \\
$N$ & 20 & 20 & 20 \\
Minimum depth $(\mathrm{cm})$ & 1.0 & 1.8 & 1.7 \\
Maximum depth $(\mathrm{cm})$ & 2.0 & 7.0 & 4.0 \\
Fractal dimensions & 1.29 & 1.32 & 1.22 \\
& & & \\
Breakdown of the area: field estimates & & & \\
\% intact red top & 60 & 45 & 20 \\
\% karren & 40 & 55 & 80 \\
& & & \\
Breakdown of the area: mapped samples & 38 & 45 & 22 \\
\% intact red top & 62 & 55 & 78 \\
\% karren & 1066 & 1066 & 1066 \\
Area measured cm ${ }^{2}$ & 1044 & 2591 & 2170 \\
Volume rock removed (cm ${ }^{3}$ ) (area x depth) & & & \\
& & & \\
Breakdown of the karren: field estimates & 5 & 10 & 5 \\
\% tubes & 30 & 70 & 15 \\
\% rods & 5 & 10 & 10 \\
\% cones & 50 & 5 & 15 \\
\% linear valley & 50 & 55 \\
\% lowland & 20 & 5 & \\
\hline
\end{tabular}

\subsubsection{Sequence of development}

For all zones the development of a tube follows breaching of the patina. The tube is the primary negative form; the rods, pinnacles, and cones are the remnants at different stages of development. Tubes that develop side-by-side eventually join up leaving parallel sheaves of rods rather like pan pipes. Rods become isolated when several more tubes coalesce. Pinnacles are produced when lateral erosion reduces the caps on top of the rods to a minimum, and cones are the result of the complete loss of caps. The cones get flatter until they are only slight hummocks. As more of the patina is removed, and more of the tubes amalgamate, valleys appear, and then widen into lowlands. The final stage is an undulating lowland with only a few remnant emergent mesas. These stages are shown diagrammatically as 5 stages in Fig. 7.

The depth of the karren depends on the rate of downcutting versus the rate of lateral extension. All zones have some newly developing tubes, some emergent rods that still have a cap of patina, some pinnacles, some cones that have lost their cap, some wider valleys and some flatter wider lowland areas, but the proportions vary. Zone A has small tubes, many rods, few cones, and little lowland. The much greater range in depths for Zone B result from the two populations: the newly-formed small tubes and the older deeper forms. Several of the isolated rods are at the pinnacle stage, but there is still a lot of intact patina. Zone $C$ has much more lowland, and many isolated cones, but the forms are not as deep as B. The fractal dimensions confirm the field impression that Zone B is the most dissected and $\mathrm{C}$ the least. The intricate laciness is surprising in view of the friability of the rock, but it is mainly related to the strength of the patina. Providing a cap of the patina remains intact, it protects the underlying rod. In some cases the rod under the cap is thinner than the cap itself.

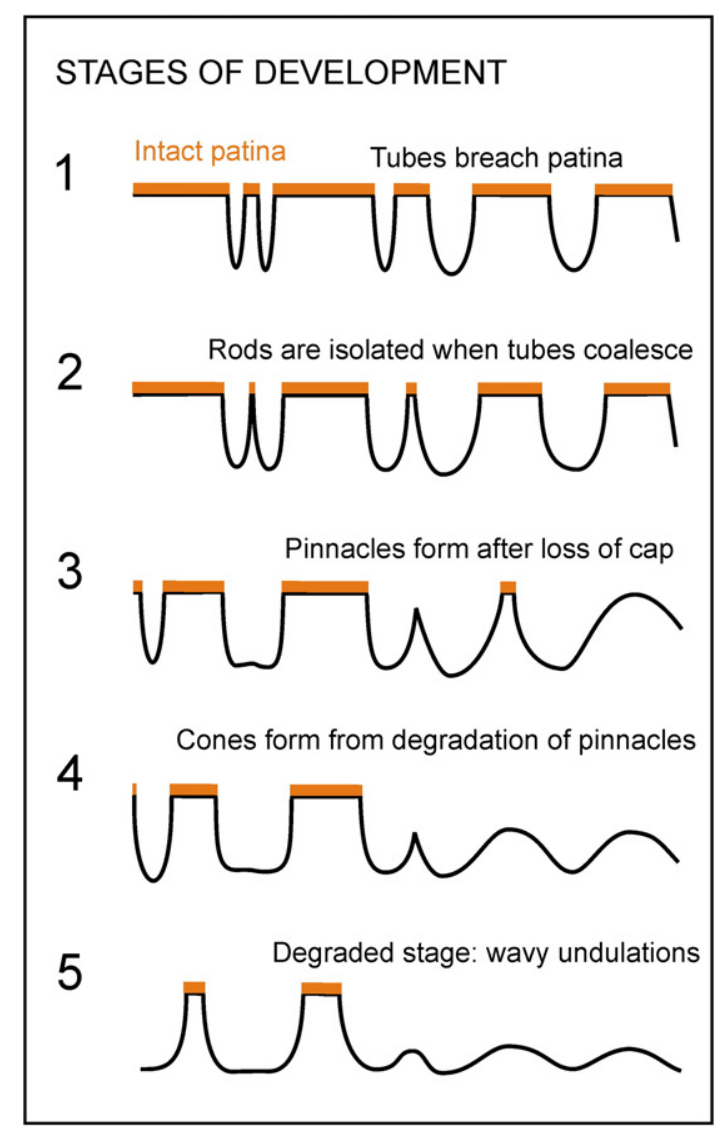

Fig. 7. Stages of development of photokarren shown diagrammatically. The iron-rich patina is the thick red line. (For interpretation of the references to colour in this figure legend, the reader is referred to the web version of this article.) 
Once the patina is gone, the form quickly loses its laciness and its panpipe shape. The strength of the patina cannot protect the rock forever so there is a limit to the length of the rods.

All three areas have probably been exposed to the light for the same amount of time (by the most recent entrance collapse). So they are all the same age and the differences do not represent different times for formation. The volume of rock removed is a measure of overall rate of erosion. Zone A has the least erosion. Zone B, with more light, has more erosion. Zone $\mathrm{C}$, although the most lit, does not have the greatest erosion.

\subsection{Geological properties}

The materials for XRD and XRF were the soft, poorly-lithified rock that hosts the photokarren; the harder red-coloured patina through which the photokarren cut; and the hard well-lithified rock that does not host photokarren. These were analyzed to understand the general nature of the material and to see if the photokarren rock was in any way distinctive. Thin sections were made of the well-lithified rock, and of the photokarren rock. These included the edge hosting the formerly-living material (now dried in alcohol). Three questions were posed: whether any evidence for dissolutional etching of surface grains could be seen; whether the cement is more often removed than the quartz grains; and whether the living material penetrates the rock as endoliths. The freshly broken rock from the photokarren region was also studied under SEM and EDS.

\subsection{1. $X R F, X R D$ and $E D S$ results}

Table 2 summarizes the XRF results for major constituents. The principal component of all three samples is silica, but the patina shows a lower content of silica and a higher concentration of iron. The well-lithified rock is very similar to the poorly-lithified rock: it shows only slightly lower Loss on Ignition (LOI), $\mathrm{Fe}_{2} \mathrm{O}_{3}$ and $\mathrm{Al}_{2} \mathrm{O}_{3}$. Trace element content was all at normal average crustal values or lower.

The XRD spectrum corresponds to quartz for all three samples. However, the pattern is complicated, with many small peaks that cannot clearly be matched to known minerals. One minor component of the two rocks matches the pyrophyllite spectrum. For the patina, iron oxide (in any form) did not come up as a possible match, but it also did not match well with any iron hydroxide (such as goethite). However, the absence of a match is not proof of the absence of a

Table 2

Rock composition.

\begin{tabular}{lrrr}
\hline & Rock & PK rock & Patina \\
\hline $\mathrm{L} . \mathrm{O} . \mathrm{I} . \%$ & 0.88 & 2.05 & 2.97 \\
$\mathrm{SiO}_{2} \%$ & 95.15 & 94.08 & 84.25 \\
$\mathrm{Al}_{2} \mathrm{O}_{3} \%$ & 2.17 & 4.06 & 0.93 \\
$\mathrm{Fe}_{2} \mathrm{O}_{3} \%$ & 0.33 & 0.37 & 11.02 \\
$\mathrm{CaO} \%$ & 0.21 & 0.08 & 0.52 \\
$\mathrm{~K}_{2} \mathrm{O} \%$ & 0.01 & 0.03 \\
$\mathrm{MgO} \%$ & 0.07 & 0.04 & 0.06 \\
$\mathrm{Na}_{2} \mathrm{O} \%$ & 0.09 & 0.08 & 0.07 \\
$\mathrm{P}_{2} \mathrm{O}_{5} \%$ & 0.20 & 0.01 & 0.17 \\
$\mathrm{TiO}_{2} \%$ & 0.03 & 0.10 & 0.17 \\
$\mathrm{Ba} \mathrm{ppm}$ & 0.09 & & 22 \\
$\mathrm{La} \mathrm{ppm}$ & 105 & & 15 \\
$\mathrm{Sr}$ ppm & 32 & & 14 \\
$\mathrm{~V} \mathrm{ppm}$ & 16 & 168 & 47 \\
$\mathrm{Zr} \mathrm{ppm}$ & & 17 & 94 \\
$\mathrm{Ce} \mathrm{ppm}$ & 92 & & \\
\hline $\mathrm{L}$ & 31 & & \\
\hline
\end{tabular}

L.O.I. = Loss on Ignition; 'Rock' is the hard well-lithified rock that does not host photokarren; 'PK rock' is the delicate, friable, poorly-lithified rock that hosts the photokarren; and 'Patina' is the red-coloured patina into which the photokarren is cut. Only those results above $10 \mathrm{ppm}$ are included. The trace element concentrations are all either at normal crustal values or below. Note: elemental content is expressed as \% oxide, but this does not indicate that the species is indeed an oxide.
Table 3

EDS (energy dispersive spectral) analysis on rock surfaces.

\begin{tabular}{lclllll}
\hline Material & Si at.\% & O at.\% & Al at.\% & Fe at.\% & Na at.\% & Ti at.\% \\
\hline Quartz grains $n=6$ & $27 \pm 6$ & $73 \pm 6$ & & & & \\
Cement $n=7$ & $21 \pm 5$ & $72 \pm 6$ & $5 \pm 4$ & $1.8 \pm 1.4$ & & \\
Cement in red patina $n=5$ & $23 \pm 7$ & $58 \pm 16$ & $2 \pm 3$ & $17 \pm 18$ & $0.3 \pm 0.8$ & \\
Iron powder $n=4$ & $5 \pm 5$ & $12 \pm 9$ & $1 \pm 1$ & $81 \pm 11$ & $0.2 \pm 0.2$ & $1 \pm 1$ \\
\hline
\end{tabular}

Values are given as atomic percentage.

mineral, and the presence of lots of 0 from EDS analysis (below) suggests that it is indeed a form of Fe-oxide.

Energy dispersive spectral analysis measures only the elemental composition of the surface. All surfaces showed some carbon, probably from the unavoidable bacteria. Table 3 summarizes the EDS data as atomic percentage (omitting carbon). The quartz grains are pure $\mathrm{SiO}_{2}$ while the inter-quartz cement shows a more complex silicate composition including some $\mathrm{Al}$ and Fe (but only 1.8\%). The cement in the red patina shows distinctly more Fe (17\%). The sample of red patina that was imaged by SEM was close to a photokarren pit. On the surfaces and interstices between grains an amorphous powder was found. This proved to have extremely high Fe content (81\%) along with a little Ti. Fig. 8 shows the SEM image (taken in Back Scattered Electron - BSE mode) of the edge of the red patina, showing the quartz grains, inter-granular cement, and the amorphous iron-rich powder. The quartz grains generally have a relatively smooth surface, while the non-quartz inter-granular material is more bladed and flaky. The Fe-powder shows up as bright white.

\subsubsection{Thin section results}

The rock is a quartz arenite (Fig. 9), with only 5-15\% non-quartz matrix material. The non-quartz inter-granular material is a phyllosilicate with undulose extinction and bright birefringence colours. It presents as either flakes, fibres (some with radiating habit), or compact masses. The composition of the phyllosilicate material is not conclusive from either visual cues or chemical data. Visual appearance in thin section, and one of the XRF spectra matches with pyrophyllite - $\mathrm{AlSi}_{2} \mathrm{O}_{5} \mathrm{OH}$ - but the EDS analysis on the cement shows only $2 \% \mathrm{Al}$ (atomic \%). In thin section the mineral shows similarity with mica $-\mathrm{KAl}_{2}\left(\mathrm{AlSi}_{3} \mathrm{O}_{10}\right)(\mathrm{F}, \mathrm{OH})_{2}$ or $(\mathrm{KF})_{2}$ $\left(\mathrm{Al}_{2} \mathrm{O}_{3}\right)_{3}\left(\mathrm{SiO}_{2}\right)_{6}\left(\mathrm{H}_{2} \mathrm{O}\right)$ - but very little $\mathrm{K}$ and no $\mathrm{F}$ was detected by XRD$\mathrm{XRF}$ or EDS analysis.

For both rocks the quartz grains are relatively well sorted, all being medium to coarse sand in size. The original rounding of the sedimentary grains is obscured by pressure-solution and re-crystallization. Many grains have been recrystallized and partly annealed, forming triple-point contacts with surrounding grains. Many grains show overgrowths of quartz.

The rock that hosts the photokarren differs from the harder rock only in grain size and quartz proportion. Fig. 9 shows the two rocks side-by-side. The lithified rock sample is taken from one of the hardest beds in the cave while the photokarren rock is one of the softest beds. The hard rock has larger grains overall, at an average of $170 \mu \mathrm{m}$ diameter (ranging from $\sim 100$ to $450 \mu \mathrm{m}$ ), while the photokarren rock has an average grain size of only $120 \mu \mathrm{m}$ (ranging from $\sim 70$ to $200 \mu \mathrm{m}$ ). The lithified rock also has a smaller proportion of non-quartz material at $\sim 5-10 \%$ while the photokarren rock has $\sim 10-15 \%$ (measured as area of thin section).

A thin section was also made cutting through the floor of the photokarren lined with organic material. No evidence was seen in this thin section for dissolutional etching of grains or cement (however, SEM studies, documented below under Section 3.3, showed several examples). It is apparent that the grains are released rather easily, leaving behind their mold. In several cases single grains are still emergent, held in place by organic material. While there is no clear evidence from the thin sections for chemical etching, there is certainly evidence against mechanical shearing or abrasion. Organic material 


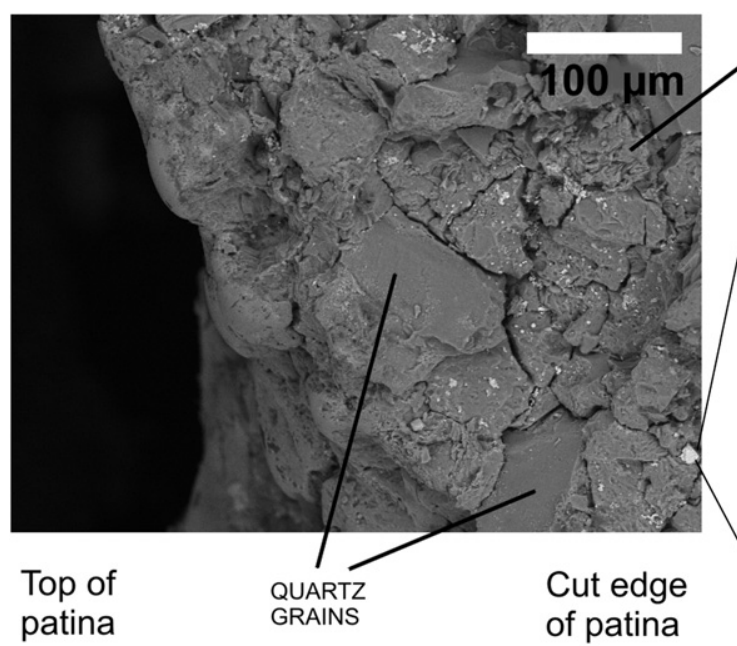

\section{CEMENT}

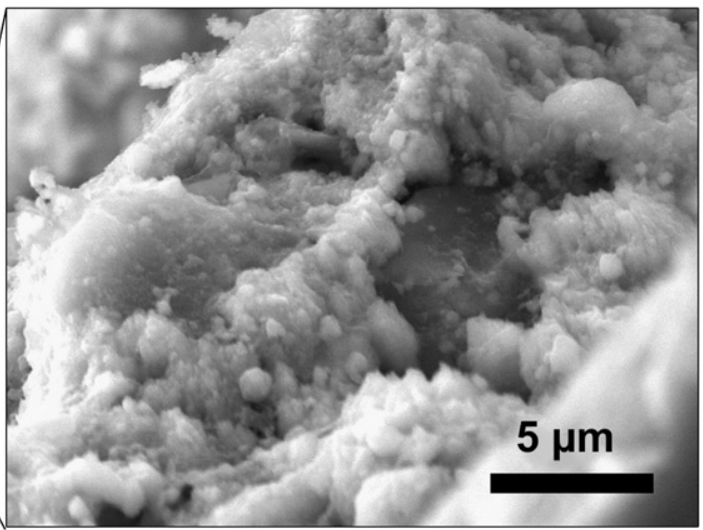

Detail of Fe-powder

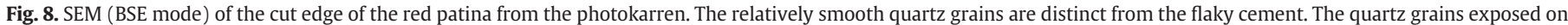
the natural top of the patina (to the left) are quite polished and rounded. The iron-rich powder appears as a white amorphous material.

can be seen to coat the surface of the grains and reach a depth of about $150 \mu \mathrm{m}$ into interstices. In this respect the organisms can be considered to be epilithic and chasmoendolithic (Golubic et al., 1981) because they live in pores on the surface, but they are not euendolithic or cryptoendolithic in that they do not penetrate the rock, there is no green layer distinctly separated from the surface, and no direct boring is apparent. Fig. 10 shows an example of organic material on the surface - the green-brown cutan that is visible on the plane polarized light image.

Although details of this uppermost unit of the Mataui Formation have not been published elsewhere, these results generally fit with published results on other samples from the Roraima Supergroup.
Samples of Roraima quartzose sandstone are reported as $>93 \%$ silica, and $<7 \%$ feldspars in one study, and 95\% quartz, 3.4\% combined $\mathrm{SiO}_{2}$, $0.1 \% \mathrm{Al}_{2} \mathrm{O}_{3}$, with very minor $\mathrm{MgO}, \mathrm{Fe}_{2} \mathrm{O}_{3}, \mathrm{CaO}, \mathrm{TiO}_{2}$ and $\mathrm{K}_{2} \mathrm{O}$ (Aubrecht et al., 2008a). Apart from smaller grain size and greater proportion of cement, there appears to be little unique about the rocks hosting the photokarren.

\subsection{Biological observations}

The photokarren are obviously associated with organic material Fig. 4 shows the green colour of the surfaces inside the photokarren contrasting with the red patina that is largely devoid of organic
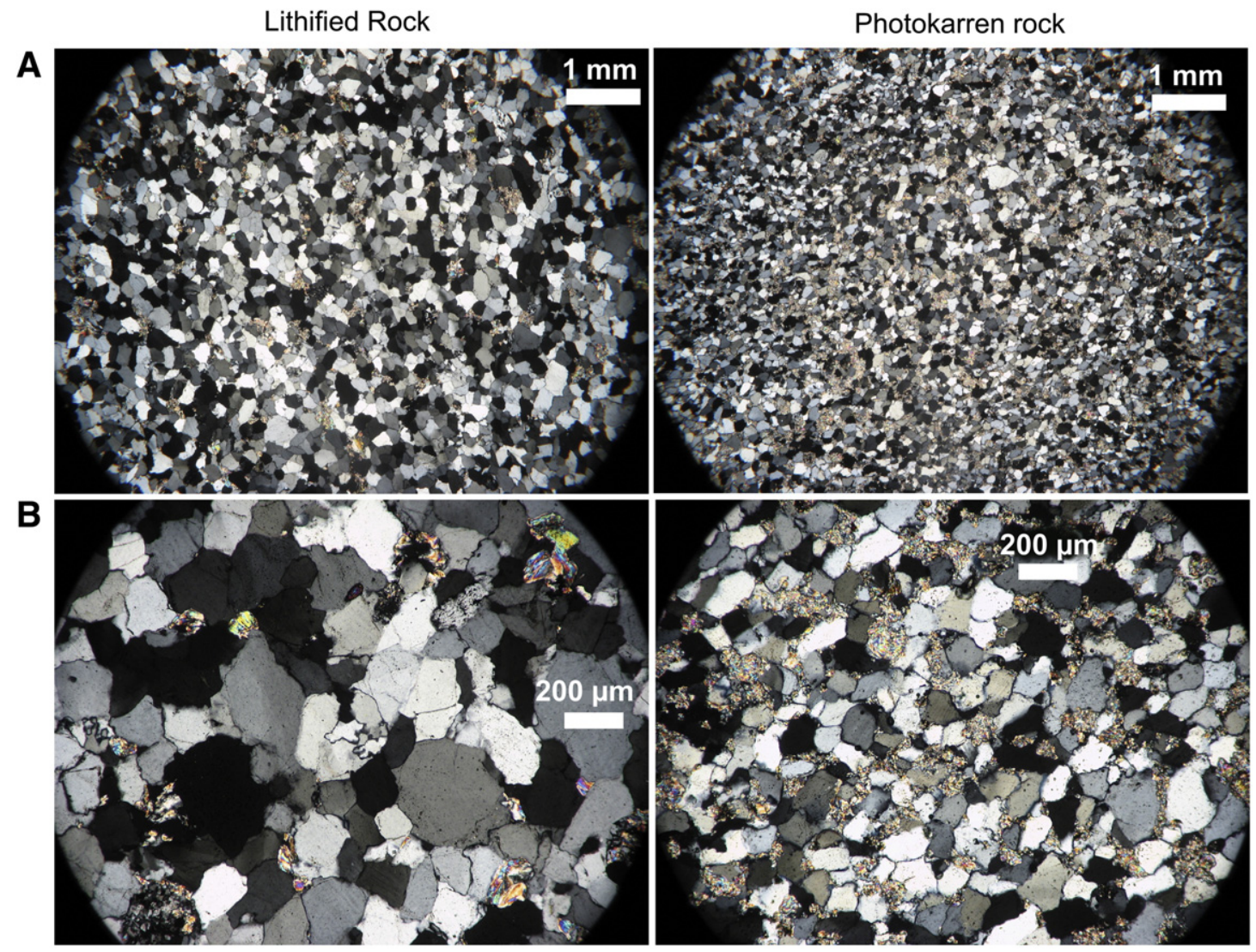

Fig. 9. Thin sections of the two rocks shown under crossed nicols. A is at the smaller scale, B is at the larger scale. 

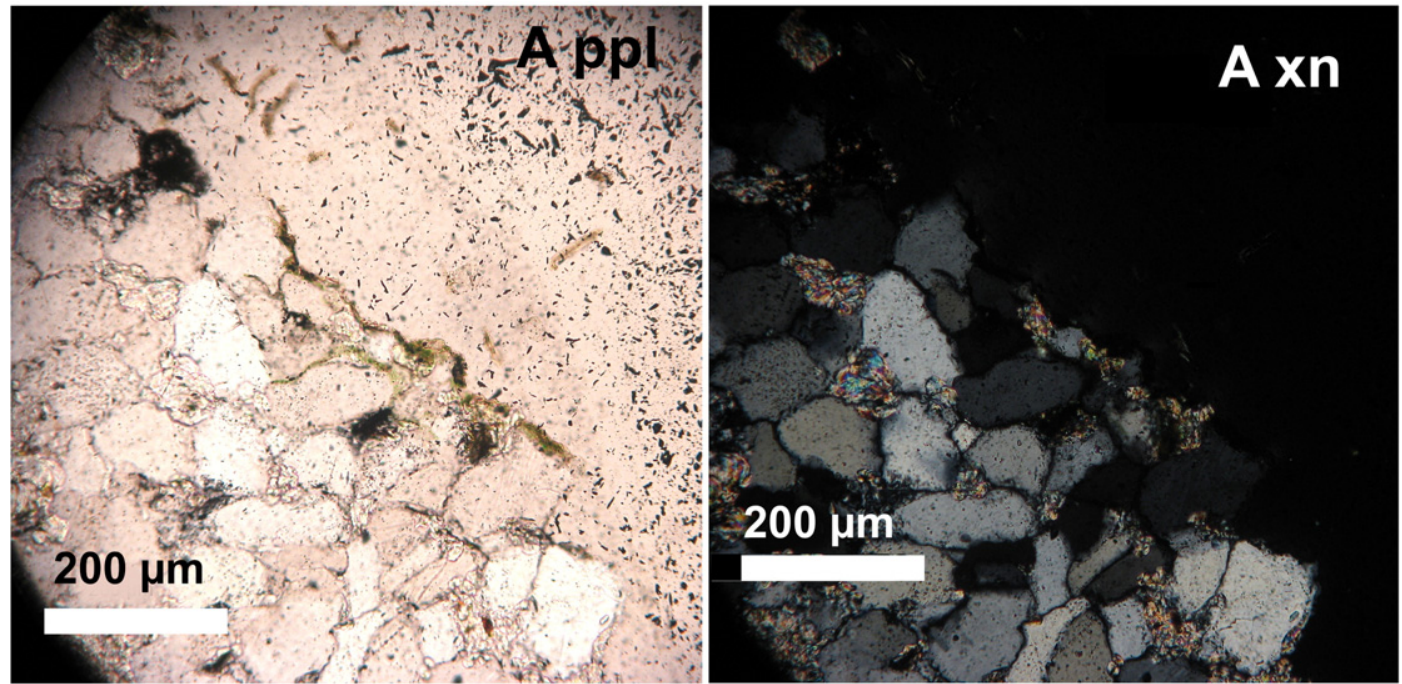

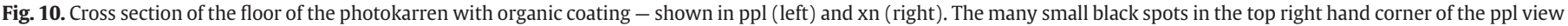
are from the impregnating resin.

material. The white flanks of the photokarren have no macroorganisms but do have some micro-organisms, and the green floors of the photokarren comprise a low diversity community, both on the macro- and micro-scale. The composition and distribution of the organic material was investigated to document the relationship of organic activity and karren morphology.

\subsubsection{Composition of the biological material}

The largest of the green organisms is liverwort, apparent to the naked eye. At least three types are present (identified by Linda Ley) the larger thalloid liverwort (Fig. 11A) forms thin ribbons that overlie other organisms, covering about $25 \%$ of the surface in the greenest parts. This is identified as in the family Aneuraceae (several Aneura species are confirmed on the nearby tepui of Roraima: Hässel de Menéndez, 2006), and most probably a Riccardia sp. - based on nine of the eleven Aneuraceae listed in the plants of Guianas being Riccardia (Boggan et al., 1997). The other two, less common, covering only 5\% of the greenest parts, are smaller, leafy liverworts. The larger (Fig. 11B) is in the family Geocalycaceae, most likely a Lophocolea sp. (seven out of the twelve Geocalycaceae listed in Boggan et al., 1997 are Lophocolea). The other (Fig. 11C) is tentatively identified as belonging in the family Calypogeiaceae (nine Calypogeia species are listed in Boggan et al., 1997).

The majority of the living material on the floor of the photokarren is webs of filamentous algae. Several types could be distinguished. The most common (Fig. 11D, G) is a red alga (Rhodophyta). This was identified (by Robert Sheath and Paul Hamilton) as a member of the genus Audouinella and probably A. hermannii. Fig. 11D shows red algal filaments that had originally been attached to a sand grain and presumably helped to displace it from the surface. They are also epiphytic on the liverworts. The less common, bright green filaments with longer cells (Fig. 11E, D) are green algae (Chlorophyta). The reticulated chloroplasts suggest that these are probably one of the cosmopolitan family Cladophoraceae.

The SEM study of the organic mat revealed thick colonies of diatoms. These were mainly directly on the rock surface, but they also colonized any surface that was handy - such as the filaments or the liverworts. Fig. 12A shows the rounded surface of the rock grain completely obscured by diatoms. Several species were noted (identified by Paul Hamilton): the most common and largest are Eunotia genus. Most of these lie in loose clumps; a few remain still attached so as to form short pseudo-filaments These are the larger diatoms in Fig. 12A, B, C and D. The smaller, less common, lozenge- shaped diatoms are Achnanthidium genus (Fig. 12B). These are the most common diatoms that are epiphytic on the algae.

The SEM also revealed a community of even smaller organisms. The most common of these are $2-3 \mu \mathrm{m}$ long, rod shaped (Fig 12B, C, D, E) and are probably true bacteria since they appear to be colourless in light microscopic view. Some very delicate filamentous bacteria were seen (Fig 12E), along with many smaller coccoid and other forms (Fig. 12C, D, F). In Fig. 12B many of the rod-shaped bacteria can be seen to lie in a depression that conforms to their shape - a "home scar" on a tiny scale. This is clear indication that the bacterium produced the hole: Viles (2009) notes that the home scars of organisms such as limpets are probably produced by a combination of physical and chemical processes, but here the process is probably entirely chemical since the bacteria are unlikely to cause any physical impact on silica.

The most complex ecosystem and thickest part of the greenery harbours a population of oribatid mites. Fig. 13 shows an adult (left) and deutonymph (right). These were identified (by Valerie BehanPelletier) as Oribatida: Malaconothridae: Trimalaconothrus maior (Berlese, 1910) (see also Behan-Pelletier et al., 1993). These mites are probably 'microbivorous' in that they will eat any microorganism, and omnivorous. They were observed eating the vegetation and rotifers. They are also likely to be detritivorous where they ingest algae-covered particles and often break them up in the gut, ejecting smaller particles. Obviously the particles must already be small enough to fit the mouthparts (presumably only up to $\sim 40 \mu \mathrm{m}$ ) so the mites are probably not responsible for the initial release of the grains from the rock matrix. However, they may be important in the further reduction of, and removal of grains. Mite distribution is limited to the thicker green mats, and thus to the photokarren floors. The population of the greenest parts was roughly estimated, from the number captured in each scraping, at $\sim 5-10$ per $\mathrm{cm}^{2}$.

\subsubsection{Distribution of biological material}

The photokarren can be imagined as a landscape where a plateau is dissected into 'valleys' with remnant flat-topped 'mesas'. The greenest parts of the photokarren surfaces are the valley bottoms that most directly face the incoming light at $30^{\circ}$. There is an obvious diminution of greenery for any other angle. The mesa flanks that are sub-parallel to the light are almost white. The red patina into which the photokarren are cut, the 'mesa' top, obviously also directly faces the light, but has minimal colonization. Biomass was estimated by the amount of green colour and the thickness of the filamentous mass. The varying thickness of biomass is indicated in Fig. 6 by the green 

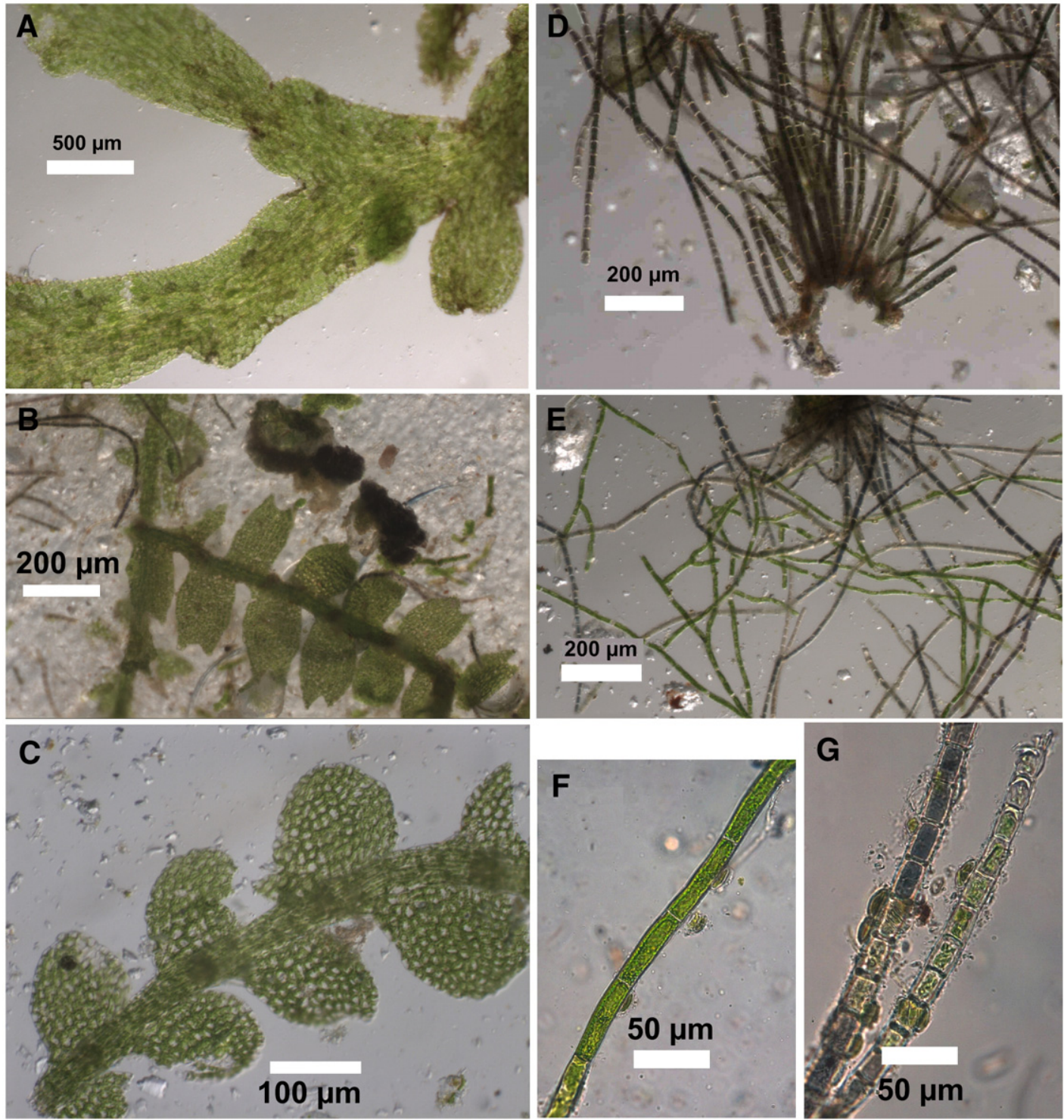

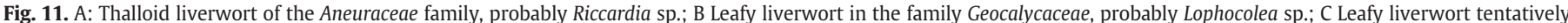

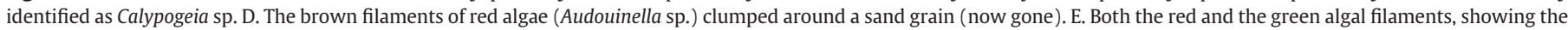

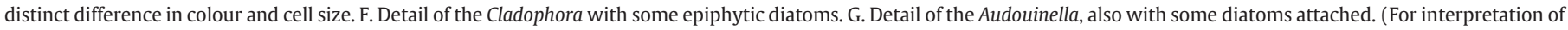
the references to colour in this figure legend, the reader is referred to the web version of this article.)

curve. For the negative forms there is a distinct association of thickness of biomass coating with depth of feature. This relationship breaks down for the degraded forms where the whole surface is wavy and more or less brown-green. The other gradient in biomass is in relation to total light levels; further back in the cave no liverworts or green algae were found.

The mesa-like flat top is the intact iron oxide patina of the original surface. Although this faces the light directly it is the driest part, mechanically the strongest, and the smoothest. It rarely has any flora, with only the very occasional patch of filaments attached to a crack (Fig. 14A). Moving into the karren flank, the pale green face of the steep cliffs, where only a little light hits at a very tangential angle, shows microscopic green material clinging mainly to the inter-granular spaces, with the quartz grains being emergent (Fig. 14B). The floor of the photokarren gets light more directly. There are two basic conditions: the first is a narrow tube or valley where light is direct and moisture is retained (Fig. 14D). This gives the most complex ecosystem with a three-storey vegetative structure that is some $1-2 \mathrm{~mm}$ emergent from the rock surface. Liverworts form the canopy, green algal and red algal mats the understorey, and (not visible here) smaller organisms the ground cover. Here the population of oribatid mites is greatest. The second situation in the floor is the more degraded stage of a much wider valley or plain where light is direct but moisture is often limited. Here the biomass mat is about $1 \mathrm{~mm}$ thick and composed of almost pure stands of red algae (Fig. 14C). The less drought-tolerant green algae and liverworts cannot survive here.

The micron scale reveals more detail. Diatoms feature surprisingly often - the only surface that was not almost completely obscured with diatoms was the red patina. All the surfaces inside the photokarren are colonized by diatoms. Much of the organism-torock contact is blurred by a mucilaginous extra-cellular polysaccharide substance (EPS - e.g., Hung et al., 2005; Marx et al., 2009); for example, the tiny piece of rock not covered by diatoms in Fig. 12A is rounded, and obscured by coccoid bacteria and EPS. Most of the surfaces from the floor of the photokarren cannot be seen because of the thick bio-mat.

The population of the smooth red patina is instructive because colonization is rare and the details of rock-to-organism contact can be clearly seen. In addition these are the pioneers in the process of 

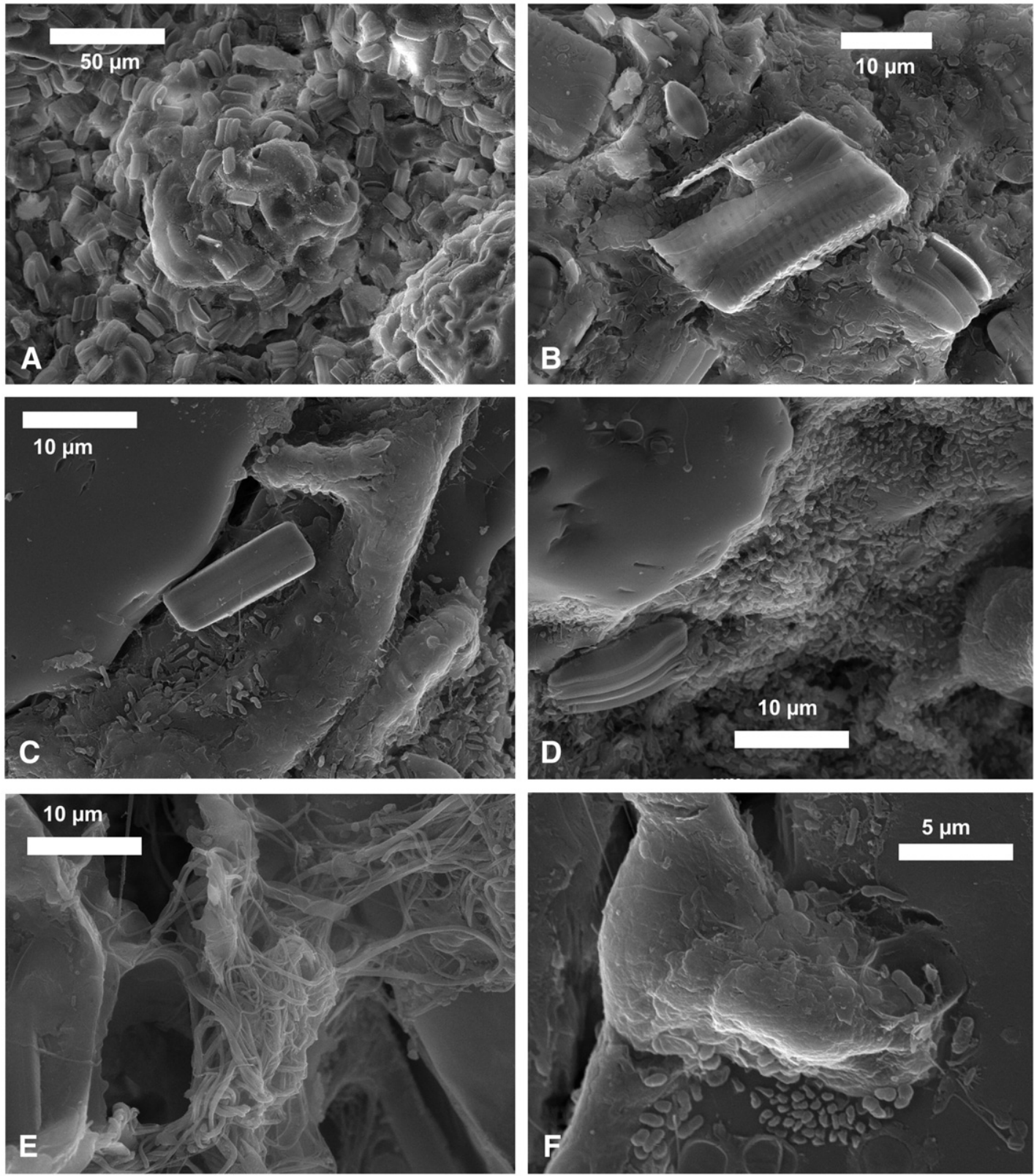

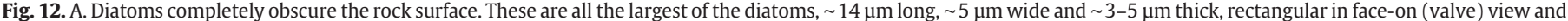

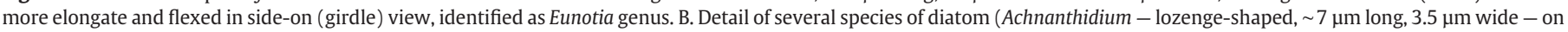

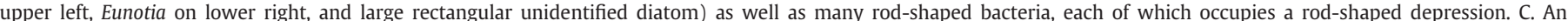

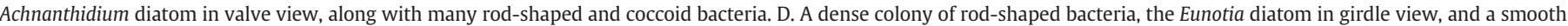

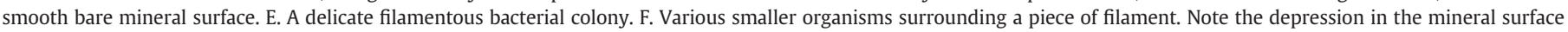
around the filament.

breaking through the patina and therefore most likely to show the effects of geomicrobiological activity. The total population is very small and limited to cracks or tiny surface roughnesses. Diatoms are dominant and rod-shaped bacteria next. Fig. 15A shows diatoms and coccoid bacteria concentrating on inter-granular regions (which can be seen to have eroded into channels) and many bacteria congregating on grain edges, the corrosion giving the grains the beginnings of dentate edges. The diatoms and bacteria prepare the way for the very few filaments that can get established. Fig. 15B shows the base pad attachment for filaments attached directly to the inter-granular cement and apparently avoiding the smooth quartz surface. This also shows the ubiquitous bacteria, again concentrating on the cement rather than the flat pure silica surface. This photograph demonstrates the beginning of pitting of the cement and separation of the grains out from the rock. One lovely example was found on the patina where a pine pollen grain (not, of course, implicated in the corrosion) had lodged in a crevice, surrounded by diatoms and rod bacteria (Fig. 15C).

When we move from the bare patina to the flanks of the karren, the surfaces that look virtually bare to the naked eye are almost completely covered by diatoms and the relief becomes greater as the inter-granular cement is removed so that the (diatom-coated) grains emerge (Fig. 15D). Filaments are sometimes seen to be attached to emergent sand grains but more often they attach invisibly in the depths of a crevice. Lots of rod-shaped bacteria can also be seen where there is a little space (e.g., Fig.12A, B). Moving down the steep faces to the bottom of the hollow, filaments gradually become more dominant. Underneath the filaments, the population of diatoms is 


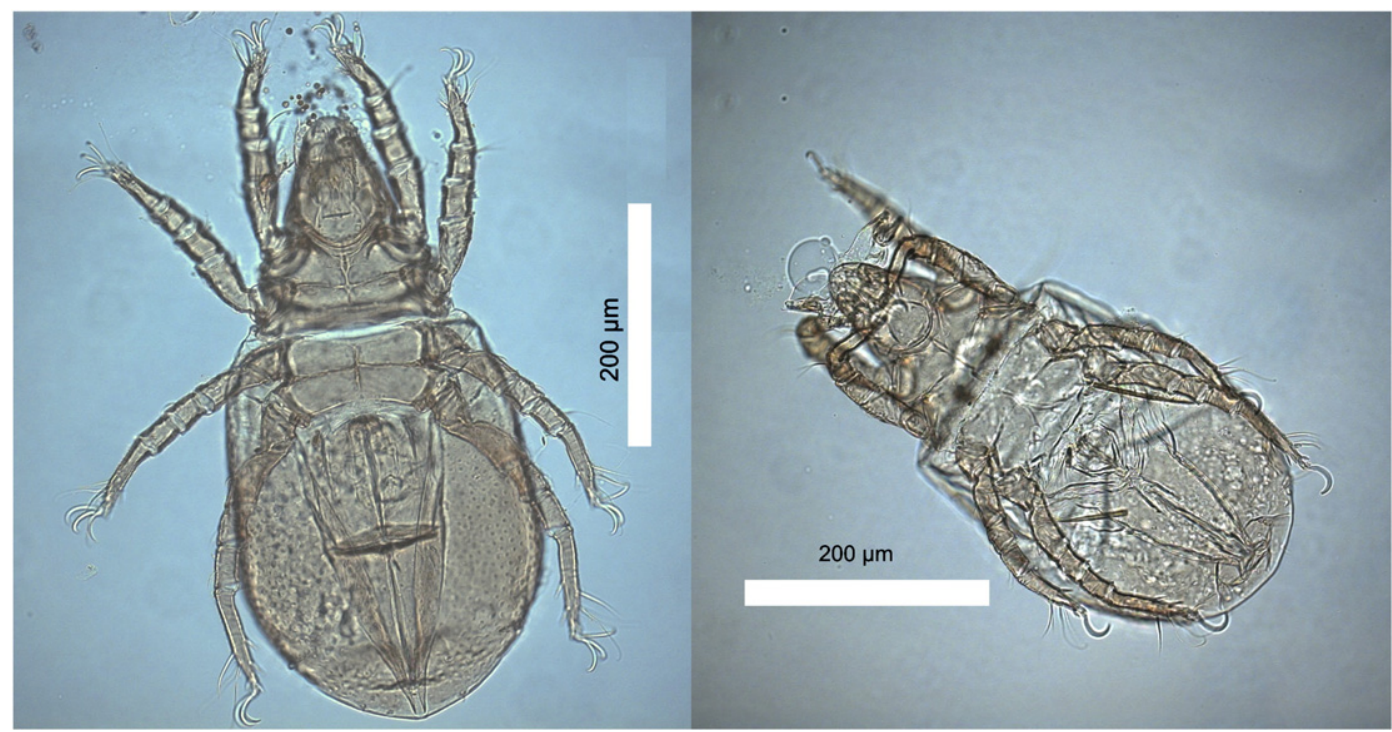

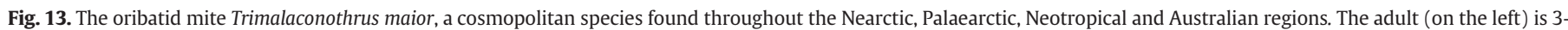
dactyle, while the nymphs (on the right) and larvae are 1-dactyle.

still rich. Fig. 15E shows the increasingly dense forest of filaments emerging from a crevice.

Down in the hollows of the photokarren, the thick mat of filaments appears to be dense, but actually the network is quite open, with lots of light reaching to the understorey of diatoms. Filaments colonize the crevices or any surface where they can get purchase, even on the liverwort (Fig. 15F). All the loose, rounded grains have a core of quartz, but the visible surfaces are coated in diatoms and EPS.

\section{Discussion}

\subsection{Erosion mechanism}

The obvious question is how these intricate features have formed, why they remain in this mechanically weak rock, and why they are not destroyed by normal speleogenetic activity. Morphology is often a good indication of mode of formation, and the sequence of development
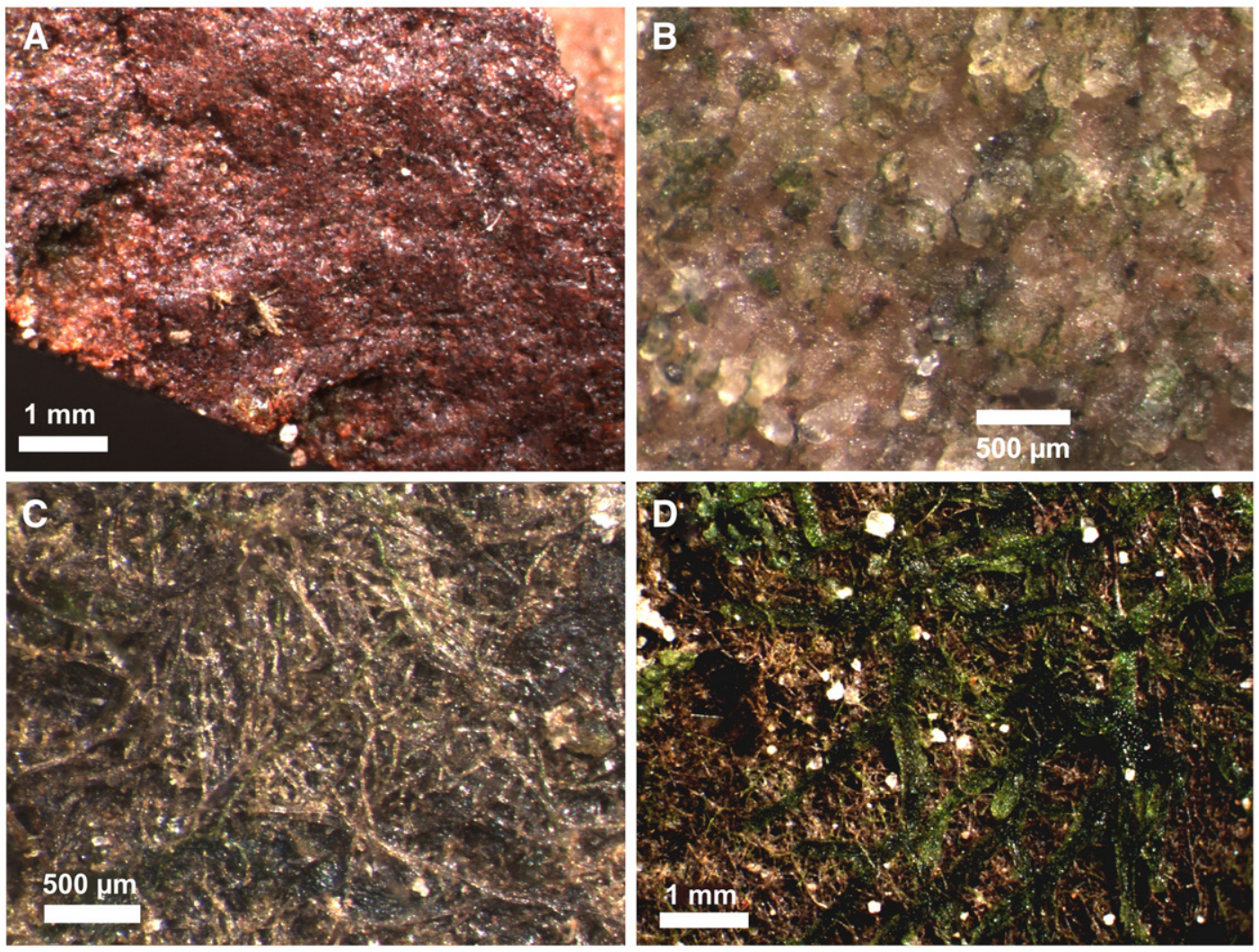

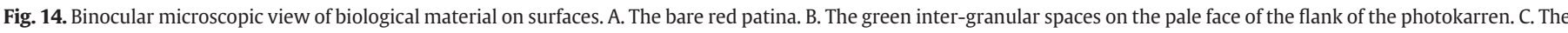

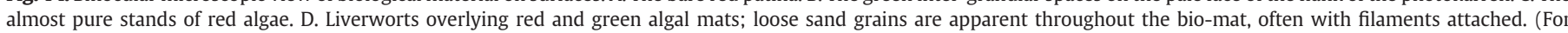
interpretation of the references to colour in this figure legend, the reader is referred to the web version of this article.) 

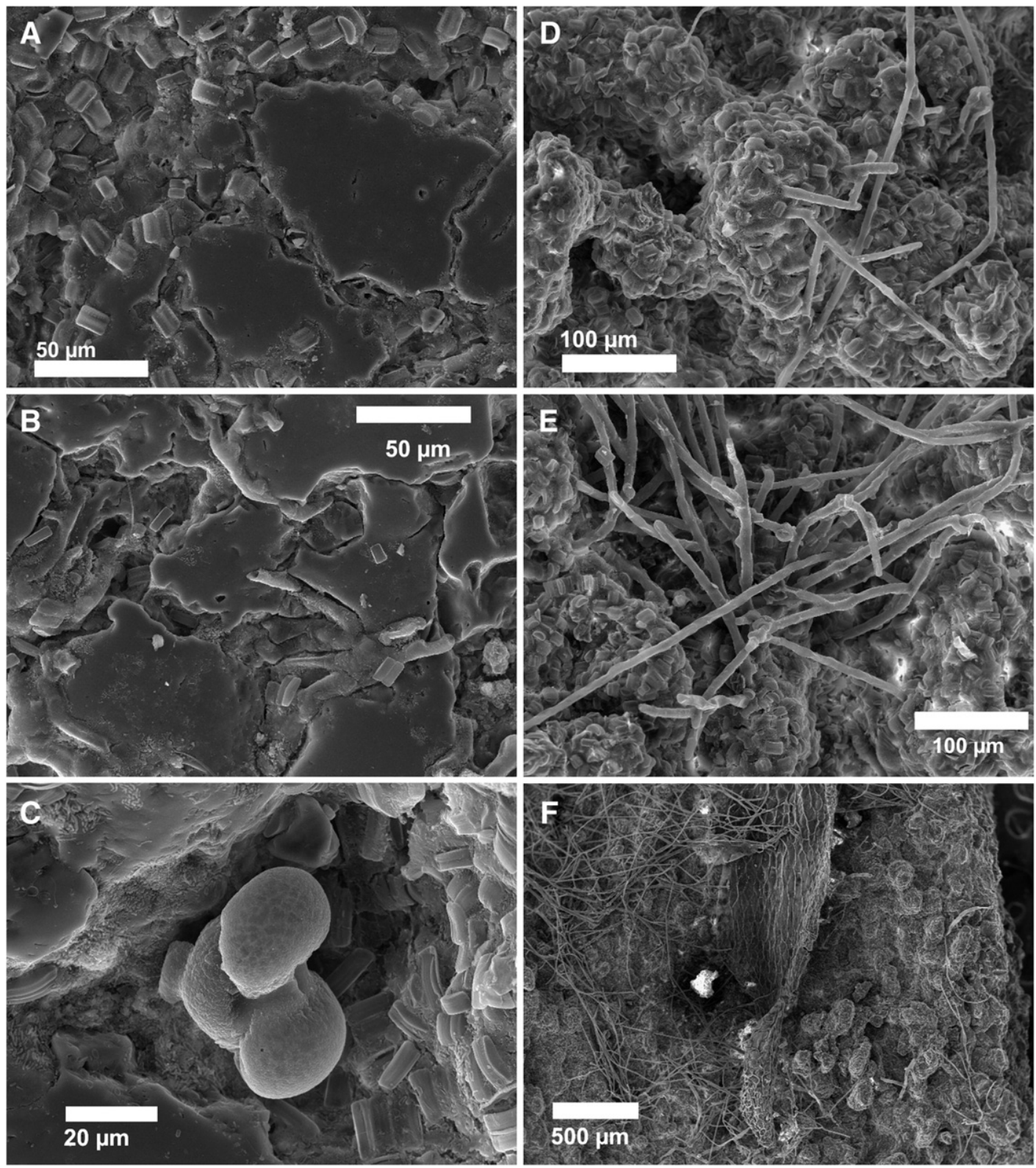

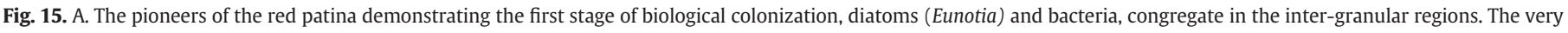

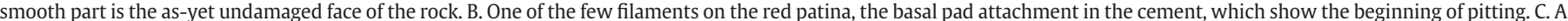

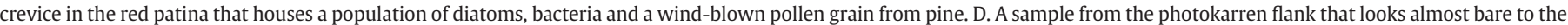

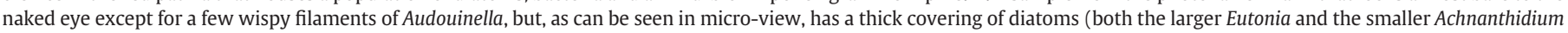

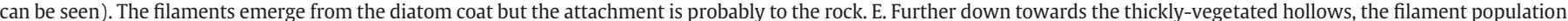

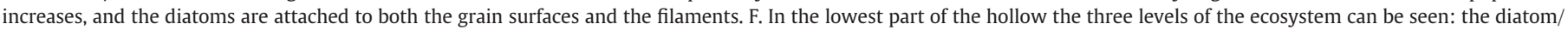
bacterial ground cover, the red algae filament intermediate level, and the upper thalloid liverwort level (which is itself colonized epiphytically by the filaments).

presented above explains how the shapes develop and how the basic features of all of the photokarren described in the literature can be reconciled into a single model. However, we still need to examine the underlying mechanism of the erosion process. The contenders are chemical, biological, and mechanical activity.

\subsubsection{Role of chemical activity}

While potentially much slower than dissolution in carbonate rocks, chemical attack, especially on the cement, is a reasonable proposition. Piccini and Mecchia (2009), in trying to explain speleogenesis in tepuis, note that the quartz overgrowth morphology facilitates rock disintegration because it is not necessary to remove all of the cement - just the overgrowth along the grain boundary. They argue that the alteration of the sandstone rock to loose grains (called 'arenization') acts where a film of water keeps the rock wet, and low velocity allows long reaction times. Inter-granular dissolution of quartz forms fine sands that are easily removed by running waters.

Although Aubrecht et al. (2008b) note that dissolution is only a very minor component of speleogenesis, Lánczos et al. (2007) did find that the cave condensation water, when first formed, is very undersaturated in $\mathrm{SiO}_{2}$ and thus extremely corrosive. It causes continual release of sand grains from the cave walls. The photokarren are in the cave entrance zone that could be expected to get maximum condensation (e.g., see Tarhule-Lips and Ford, 1998). However, for this to explain the morphology of the photokarren, we have to find a mechanism to restrict the condensation first to patches of the patina and then to the base of the tubes, and always in relation to light - an unlikely proposition. 
So, for the photokarren, it looks like direct chemical dissolution is probably not important but that arenization could be caused by other processes.

\subsubsection{Role of biological activity}

Everywhere that they have been reported, photokarren are associated with biological action and it is generally presumed that biogeomorphological activity explains their formation. However, Viles $(2004,2009)$ has noted, for phytokarst in general, that it has proved difficult to determine the exact role of biological agents in their formation, to link the micron-to-millimeter scale with the centimeterto-meter scale. Making a convincing link between biofilm processes and phytokarst has proved to be difficult - there may be a range of processes operating at different scales. The fact that photokarren are forming quite happily in this non-carbonate environment calls into question the assumption made in the other two studies that boring must be the principal causative agent.

There are two potential effects of organic activity: 1 . specific and direct effects from particular organisms; and 2. general effects from the presence of biological activity. Two examples of the first are apparent here. None of the organisms seen here directly bores the substrate, but the SEM images show several examples of what looks like direct corrosion of the quartz surfaces by bacteria. This is true even of some very smooth surfaces but more of the inter-granular cements. The second example is the detachment of grains by the load of filaments or possibly by the contraction-expansion of filaments through dryingwetting cycles. Viles (2009) notes that the considerable stresses from expansion of epilithic and chasmoendolithic organisms can cause flaking and granular disintegration.

The rest of the effects of biological activity fit under the second case general biological activity. While direct pitting of surfaces could not be seen (perhaps because so many of the rock surfaces were obscured), there is a definite favouring of the inter-granular area by organisms and there are several examples of deep inter-granular canyons that were probably produced by biochemical attack. The function of the diatoms is not immediately obvious because it looks like they form a protective coat (although they must get the silica for their walls from somewhere). In several of the images the edges of the diatoms are hidden by a biofilm of bacteria-EPS complex (e.g., Fig. 12A, B, 12D). The diatoms are a major part of this biofilm that coats the surfaces. EPS is known to bind metals (e.g., Hung et al., 2005; Pal and Paul, 2008) and this may be important for rock corrosion. However, while there may be additional complex biochemical processes in action under here (e.g., see also Northup and Lavoie, 2001; Boston, 2004), erosion is probably effected by the simple presence of biological activity, and its concomitant acidity and moisture in intimate contact with the rock surface. Cyanobacteria are known to have important direct impacts on erosion (e.g., Wessels and Budel, 1995; Gorbushina, 2007), and they have been identified in the other terrestrial photokarren study (Bull and Laverty, 1982). Yet, it is of interest that cyanobacteria do not appear to be important here.

The location of the most biological activity is thus directly implicated in the location of the most erosion. Here we found a very simple and direct relationship between the biomass and the erosion, so it is strange that Bull and Laverty (1982) found no relationship between form and biomass. It is important to differentiate between those organisms that cause corrosion and those that simply occupy a substrate. A detailed reading of the Bull and Laverty paper suggests that the red algae are simply opportunistic, colonizing the surface after the karren had already formed, while the cyanobacteria were indeed found to be concentrated in the hollows and thus likely to be the causative agents. In the case of the Cueva Charles Brewer photokarren, the red algae are also probably opportunistic, as are the oribatid mites and the liverworts. The bacteria and diatoms that initiate the corrosion through the hard red patina are the pioneers that trigger the subsequent enlargement of the tiny ecosystem which then extends in the direction of the greatest photosynthesis.

\subsubsection{Role of mechanical activity}

No form of direct mechanical action operates here. The site of the photokarren is isolated from fluvial abrasion, from any roof drips, from any eolian activity. It also appears that bio-mechanical boring does not occur. However, bio-mechanical transportation may be important. The filaments colonize the sand surface and simply pick up the already-loosened particles en masse. Much of the removal of grains is inadvertent as the filaments grow outwards. The other agent of removal is probably the oribatid mites. They are detritovores - so they probably do not take the particles until they have already been loosened.

\subsection{Comparison of Venezuela sandstone photokarren with other photokarren}

These photokarren seem to include all the features mentioned in the other examples from Borneo and Ireland, and all are simply stages in development from tubes, through rods, pinnacles, cones, to wavy forms. The model for development that we describe above explains this particular site, but it has the added benefit of integrating all the published details for photokarren features into a single unified theory. All the stages are represented to varying degrees in all three locations. The features from Ireland are largely tubes and pinnacles. The features from Mulu are largely at the pinnacle and cone stage with some almost completely degraded stages. The bladed or striated forms develop where deep or shallow tubes coalesce along lines.

Our observation that there are more cones closer to the entrance at first appears not to conform to Bull and Laverty's (1982) observations from Mulu. They noted that the further into the cave, the more coneor rod-like form; and the further towards the entrance the more broad the angle of the larger forms. However, the Mulu example is over a much larger distance range and a much greater range of sizes. The Venezuela example does not have the large wavy forms of Mulu - it only has small wavy forms (the undulating lowlands). It is more the equivalent of only the rod and cone zone of Mulu.

\subsection{Age of the features}

These features are very likely to form rapidly - probably much more rapidly than karren on limestone. The cave is very delicate, much of the rock being quite fragile, with apparently rather frequent collapse events. The active nature of the cave may also be a factor in that the present river level is only temporary. The beginning of undercutting a little farther upstream is apparent, so that this surface will presently collapse. So the time for photokarren development will be limited by the rate of cave floor collapse. While there is no obvious way to measure the age of these features, we suggest that these individual features may be no more than 500 years old. Before this time a previous suite may have occupied the zone of low light levels on a surface that had been higher than the present and has since been cut down to the present level, or that had been closer to the cliff line, when the entrance had not yet collapsed back as far as it is today.

\subsection{A model for photokarren development}

The development of the photokarren goes hand-in-hand with the development and alteration of the micro-ecosystem. This is a system where any differential erosion is likely to be self-perpetuating, so the challenge is largely to get it started.

In all cases the beginning has to be the successful establishment of photosynthetic organisms on a patch of the rock surface. Obviously light is required - but it needs to be low enough that normal vegetation cannot get established over all surfaces and focused enough to create 
points of light and points of shadow that remain in the same place. In most cases a rock surface has micro-inhomogeneities that will catch the light. Once the tubes start, they create their own shadow that ensures their continued phototropic extension.

The initial success of colonization and penetration of the surface then creates a micro-habitat more conducive to further colonization and also to more diversity. The biological succession goes hand-inhand with the niche modification that occurs as the rock is eroded. The small initial depression gets enlarged, immediately creating a more protected niche that is no longer subject to desiccation. In addition the biochemical processes that release nutrients from the substrate provide a richer environment.

The shape of the negative form depends on the rate of lateral versus vertical erosion. The tube is always slightly splayed and lateral erosion makes it wider. The centre of the wide form is then open to the danger of desiccation, thus limiting biological activity and erosion. This explains why the biomass of the undulating lowlands is thinner and less diverse than the deep narrow hollows.

In this particular case the photokarren are probably developing in a higher light level than in limestone caves (as indicated by the succession to liverworts) and it is related to the particular detail of this location - the red patina. This provides a distinct mechanical challenge to colonization that inhibits all but the toughest organisms. It seems that the photokarren form only once on this surface. If conditions remain constant (i.e., if the cave entrance does not collapse any further exposing new substrates to the correct suite of conditions), then the photokarren become degraded by lateral erosion into undulating lowlands that are generally evenly coated with browngreen material, and soon lose all traces of their former status as photokarren.

In geomorphology it can be helpful to study both the erosional feature and the deposits produced by erosion. However, this is rarely possible since the deposits are usually dispersed. Cueva Charles Brewer does have many sandy deposits, but none can be seen to relate directly to the photokarren. Obviously the products of erosion must be removed in order to continue the deepening of the photokarren pits. However, the removal of products of erosion from a narrow, deep hole that is quasi-vertical remains an unanswered question that has not been addressed elsewhere. Most photokarren are not near flowing water, they are not open to rain splash, and wind cannot get into them. Our suggestion that the filaments carry particles away from the rock surface is admittedly rather weak. One potential mechanism might be evaporative wicking of the dissolved materials up the flanks to the surface, but there is no evidence of deposition anywhere on the top. The only evidence for deposition is the strange iron-rich powder that is found in the red patina (Fig. 8) and it is probably bacterially mediated rather than evaporative.

The survival of these photokarren in a cave environment with a generally active fluvial streamway is partly serendipitous - actually some of them do get destroyed by fluvial action - and partly because the very mode of formation indicates that they are not created by normal speleogenetic activity. They are certainly not created by fluvial action. The scale of inhomogeneous cementation that explains the large-scale locations of passages and pillars in the cave is not relevant to these tiny features and no small-scale differences in cementation could be observed in the hand specimens studied. The most active of the speleogenetic processes, i.e. collapse, serves only to destroy these features. The only known mechanism of erosion that can explain these phototrophic features in this damp cave environment is erosion in association with photosynthetic organisms.

\subsection{A note on conservation}

We know details about only three examples of photokarren in the world. We know of the existence of only one in sandstone. This makes this tiny feature even more significant than the large cave it is in.
However, it is extremely vulnerable. Laverty (1983) notes that photokarren in Sarawak are a 'most delicate and fragile landform' that is all too easily crushed by visiting feet. The Sarawak examples are in hard limestone - which is infinitely tougher than the photokarren here in Cueva Charles Brewer. Every effort needs to be made to preserve them intact for the future.

\section{Conclusion}

This suite of delicate, light-oriented erosional features conforms to all the features of photokarren. It is one of only three examples worldwide that have been studied. So the range of known occurrences has now expanded from only Borneo and Ireland to include Venezuela. It is the only example from a non-carbonate environment and it is thus unique.

The sequence for development presented here relates all published forms into a unified theory. The forms of the photokarren vary with stage of development. The primary (negative) erosional form is the tube. Resulting from coalescence of tubes are the positive remnant forms of rods, pinnacles, and cones. The final stage is a somewhat bumpy, wavy surface. The size of the features varies with erosion rate.

The presence of a biofilm on the photokarren surfaces and the simple, direct relationship of the most biomass in the deepest parts suggest that biological activity is the dominant control on development. Biochemically-enhanced weathering of the cement or quartz overgrowth is the most likely cause for the granular disintegration.

\section{Acknowledgements}

The expedition was under the auspices of the Sociedad Venezolana de Ciencias Naturales. Financing and support was provided by Fundacion EXPLORA and in part by an NSERC grant to JL. Many thanks to the following: Karen Brewer for help in the field; Andreas Fitzner for in-cave photography; Tara Kell for XRD and XRF analysis; Mike Jackson for thin section preparation; Jianquin Wang for SEM; Shelly Hepworth and her graduate students for use of lab and advice; Sue Patterson and Frances Pick for helpful discussion of biological things; Linda Ley for identification of liverworts; Valeria BehanPelletier for identification of mites; and Paul Harrison and Robert Sheath for identification of diatoms and algae.

\section{References}

Aubrecht, R., Brewer-Carías, C., Šmída, B., Audy, M., Kováčik, L, 2008a. Anatomy of biologically mediated opal speleothems in the World's largest sandstone cave: Cueva Charles Brewer, Chimantá Plateau, Venezuela. Sedimentary Geology 203, 181-195.

Aubrecht, R., Lánczos, T., Šmída, B., Brewer-Carías, C., Mayoral, F., Schlögl, J., Audy, M., Vlcek, L., Gregor, M., 2008b. Venezuelan sandstone caves: a new view on their genesis, hydrogeology and speleothems. Geologia Croatica 61, 345-362.

Behan-Pelletier, V.M., Paoletti, M.G., Bisset, B., Stinner, B.R., 1993. Oribatid mites of forest habitats in northern Venezuela. Tropical Zoology 1, 39-54 (special issue).

Boggan, J., Funk, V., Kelloff, C., Hoff, M., Cremers, G., Feuillet, C., 1997. Checklist of the Plants of the Guianas. Smithsonian Institution, Washington.

Boston, P., 2004. Biofilms. In: Gunn, J. (Ed.), Encyclopedia of Caves and Karst Science. Fitzroy Dearborn, New York, London, pp. 145-147.

Brook, D., Waltham, A.C., 1978. Caves of Mulu. Royal Geographical Society, London.

Bull, P.A., Laverty, M., 1982. Observations on phytokarst. Zeitschrift fur Geomorphologie. N.F. 26, 437-457.

Folk, R.L., Roberts, H.H., Moore, C.H., 1973. Black phytokarst from hell, Cayman Islands, British West Indies. Geological Society of America Bulletin 84, 2351-2360.

Gibbs, A.K., Barron, C.N., 1993. The Geology of the Guyana Shield. Clarendon Press, Oxford.

Golubić, S., Friedmann, E., Schneider, J., 1981. The lithobiontic niche, with special reference to microorganisms. Journal of Sedimentary Petrology 51, 475-478.

Gorbushina, A.A., 2007. Life on the rocks. Environmental Microbiology 9, 1613-1631.

Hässel de Menéndez, G.G., 2006. Aneura polyclada, A. polyptera and A. denticulata (Aneuraceae) from South America, overlooked names since 1886. The Bryologist 109, 33-37.

Hung, C.-C., Santschi, P.H., Gillow, J.B., 2005. Isolation and characterization of extracellular polysaccharides produced by Pseudomonas fluorescens Biovar II. Carbohydrate Polymers 61, 141-147. 
Lánczos, T., Aubrecht, R., Schlögl, J., Šmída, B., Brewer-Carías, C.H., 2007. Preliminary results of the Tepuy 2007 Expedition to the Venezuelan table mountains - water geochemistry and its relation to the genesis of the quartzite karst. In: Flaková, R., Šenišová, Z. (Eds.), Proceedings of the Hydrogeochémia 2007 Conference, 7th-8th June 2007, Bratislava. Slovak Association of Hydrogeologists, Bratislava, pp. 136-141.

Laverty, M., 1981. A note on directed phytokarst in Sarawak (E. Malaysia). International Journal of Speleology 11, 203-206.

Laverty M., 1983. Borneo 1983 - Some Karst in the Penrissen area of Sarawak. Oxford University Cave Club Proceedings 11, http://www.oucc.org.uk/procs/proc11/ borneo_karst.htm.

Marx, J.G., Carpenter, S.D., Deming, J.W., 2009. Production of cryoprotectant extracellular polysaccharide substances (EPS) by the marine psychrophilic bacterium Colwellia psychrerythraea strain $34 \mathrm{H}$ under extreme conditions. Canadian Journal of Microbiology 55, 63-72.

National Institutes of Health, 2009. ImageJ. http://rsbweb.nih.gov/ij/.

Northup, D.E., Lavoie, K.H., 2001. Geomicrobiology of caves: a review. Geomicrobiology Journal 19, 199-222.

Pal, A., Paul, A.K., 2008. Microbial extracellular polymeric substances: central elements in heavy metal bioremediation. Indian Journal of Microbiology 48, 49-64.

Piccini, L., Mecchia, M., 2009. Solution weathering rate and origin of karst landforms and caves in the quartzite of Auyan-tepui (Gran Sabana, Venezuela). Geomorphology 106, 15-25.
Porter, E.M., 2003. Larrybane Stalactite Cave, Larrybane Bay, Antrim. National Museums Northern Ireland Website. http://www.habitas.org.uk/escr/site.asp?item $=520$.

Santos, J.O.S., Potter, P.E., Reis, N.J., Hartmann, L.A., Fletcher, I.R., McNaughton, N.J., 2003 Age, source, and regional stratigraphy of the Roraima Supergroup and Roraima-like outliers in northern South America based on U-Pb geochronology. Geological Society of America Bulletin 115, 331-348.

Simms, M.J., 1990. Phytokarst and photokarren in Ireland. Cave Science 17, 131-133.

Šmída, B., Audy, M., Mayoral, F., 2005. Cueva Charles Brewer: largest quartzite cave in the world. NSS News 63, 13-31.

Tarhule-Lips, R.F.A., Ford, D.C., 1998. Morphometric studies of bell hole development on Cayman Brac. Cave and Karst Science 25, 19-130.

Viles, H., 2004. Phytokarst. In: Gunn, J. (Ed.), Encyclopedia of Caves and Karst Science. Fitzroy Dearborn, New York, London, pp. 581-582.

Viles, H., 2009. Biokarstic processes associated with karren development. In: Ginés, A., Knez, M., Slabe, T., Dreybrodt, W. (Eds.), Karst Rock Features: Karren Sculpturing. Carstologia, 9. Založba ZRC / ZRC Publishing, Ljubljana, pp. 37-45.

Vuidel, G., 2006. Fractalyse. http://www.fractalyse.org/en-home.html.

Waltham, A.C., Brook, D.B., 1980. Cave development in the Melinau limestone of the Gunung Mulu National Park. Geographical Journal 146, 258-266.

Wessels, D.C., Budel, B., 1995. Epilithic and cryptoendolithic cyanobacteria of Clarens sandstone cliffs in the Golden Gate Highlands National Park, South Africa. Botanica Acta 108, 220-226. 